\title{
Forearc density structure of the overriding plate in the northern area of the giant 1960 Valdivia earthquake.
}

\author{
Andrei Maksymowicz ${ }^{1}$, Daniela Montecinos-Cuadros ${ }^{1}$, Daniel Díaz ${ }^{1}$, María José Segovia ${ }^{1}$, Tomás Reyes ${ }^{2,3}$ \\ $5 \quad{ }^{1}$ Departamento de Geofísica, Universidad de Chile, Blanco Encalada 2002, Santiago, Chile \\ ${ }^{2}$ Departamento de Geología, Universidad de Chile, Santiago, Plaza Ercilla 803, Chile \\ ${ }^{3}$ Instituto de Geocronología y Geología Isotopica (INGEIS-CONICET), Universidad de Buenos Aires (UBA), Argentina. \\ Correspondence to: Andrei Maksymowicz (andrei.maksymowicz@uchile.cl)
}

\begin{abstract}
The objective of this work is to analyse the density structure of the continental forearc in the northern segment of the
$101960 \mathrm{Mw}$ 9.6 Valdivia earthquake. Regional 2D and local 3D density models have been obtained from available gravity data in the area, complemented with new gravimetric stations. Models are constrained by independent geophysical/geological information and new TEM and MT soundings. The results show a segmentation of the continental wedge along and perpendicular to the margin, highlighting a high density anomaly, below the onshore forearc basin, that limits the Late Paleozoic-Early Mesozoic metamorphic basement in the region where Chaitenia terrain has been proposed. A progressive landward shift of this anomaly correlates with

15 the high slip patch of the giant 1960 Mw9.6 Valdivia earthquake. Based on these results, we propose that the horizontal extension of the less rigid basement units conforming the marine wedge and Coastal Cordillera domain could modify the process of stress loading during the interseismic periods, and also that changes in position and extension of the Late Paleozoic-Early Mesozoic accretionary complex could be linked with the frictional properties of the interplate boundary. This analysis provides new evidence of the role of the overriding plate structure on the seismotectonic process in subduction zones.
\end{abstract}

\section{Introduction}

The physical structure of the oceanic and continental plates have had an important role in the long and short-term deformation process of the subduction margins. In the other way around, the tectonic activity has modified the internal structure and geometry of the tectonic plates (i.e., Bilek et al, 2003; Hackney et al., 2006; Hicks et al., 2014; Contreras-Reyes and Carrizo, 2011; Bassett and Watts, 2015; Poli et al.,2017). This particular geodynamical feedback is evinced by spatial correlations between the physical segmentation of the continental wedge, and ruptures of large megathrust earthquakes (i.e., Contreras-Reyes et al. 2010; Li and Liu, 2017; Martínez-Loriente et al., 2019). Examples of this are the spatial correlation between gravity (density), anomalies in the continental wedge and the location of large slip patches in large earthquakes (Song and Simons, 2003, Wells et al., 2003; Bassett

and Watts, 2015; Bassett et al., 2016; Schurr et al., 2020), which suggests that changes in normal stresses on the seismogenic zone have a role on the seismic rate and slip propagation during large earthquakes (Tassara et al., 2010; Maksymowicz et al., 2015; 2018). On the other hand, those changes of the continental wedge geometry convey variations in the interplate boundary friction at the maximum slip patches of the large 2011 Mw9.0 Tohoku-Oki, 2010 Mw8.8 Maule and 1960 Mw 9.6 Valdivia earthquakes (Cubas et al., 2013a,b; Maksymowicz, 2015; Contreras-Reyes et al., 2017).

Diverse works have highlighted the importance of the transition between accretionary prism (or highly fractured frontal units) and the more rigid rocks of continental basement (backstop or seismic backstop) as a tectonic limit, controlling, at least partially, the upward propagation of coseismic slip, foreshocks and aftershocks during large megathrust earthquakes (Scholz, 1998; ContrerasReyes et al., 2010; Moscoso et al., 2011; Kodaira et al., 2012; León-Ríos et al., 2016; Maksymowicz et al., 2017; 2018 ; Tsuji et al. 40 2017). At the same time, the downdip limit of the megathrust earthquakes has been related (among other factors) to physical 
properties of mantle wedge and deep interplate boundary (Peacock and Hyndman, 1999; Seno, 2005; Wang et al., 2020), which are modified by fluids subduction, slab dehydration and presence of basal accretionary complexes (Moreno et al., 2018; Menant et al., 2019). Notwithstanding, less attention has been paid to the internal physical structure (and lithology) of the continental crust above the downward limit of the megathrust, even considering that all forearc units above the fragile/ductile limit should work as a part of the same mechanically coupled system (van Dinther et al., 2012; Comte et al., 2019).

In this context, we have explored the continental forearc density structure of the Nazca-South America subduction zone in a segment where the high slip patch of the giant 1960 Mw9.6 Valdivia earthquake ruptured (Fig. 1). As aforementioned, this slip patch correlates not only with a low gravity anomaly above marine forearc (Wells et al., 2003) and a low continental slope angles (Maksymowicz, 2015), but also, with a landward extension of Palaeozoic metamorphic outcrops onshore (Fig 1a). Fithermore, ages and petrological data of continental basement rocks (metamorphic and plutonic rocks) suggest a complex ancient history of accreted terrains (Ramos et al., 1986; Rapalini, 2005) that conforms the current continental crust in the area (Fig. 1b). Particularly, the recent proposal of an oceanic terrain accreted against Gondwana margin at Devonian time (Chaitenia, Hervé et al., 2016; 2018, $\mathrm{Ct}$ in Fig. 1b) could determine changes in the internal structure of the continental forearc, at the south of $\sim 40^{\circ} \mathrm{S}$. However, the exact limits of this basement configuration remains poorly constrained. In order to reveal the crustal structure of this active portion of Chilean margin, this work present the results and interpretation corresponding to regional 2D density models, extended from Nazca plate to Andes Cordillera (Fig. 3), and a local 3D density model of continental forearc (red rectangle in Fig. 2, and 3). The models include magnetotellurics (MT) and transient electromagnetic (TEM) measurements, as well as, available independent geophysical and geological data to constraint forward modelling and 3D inversion.
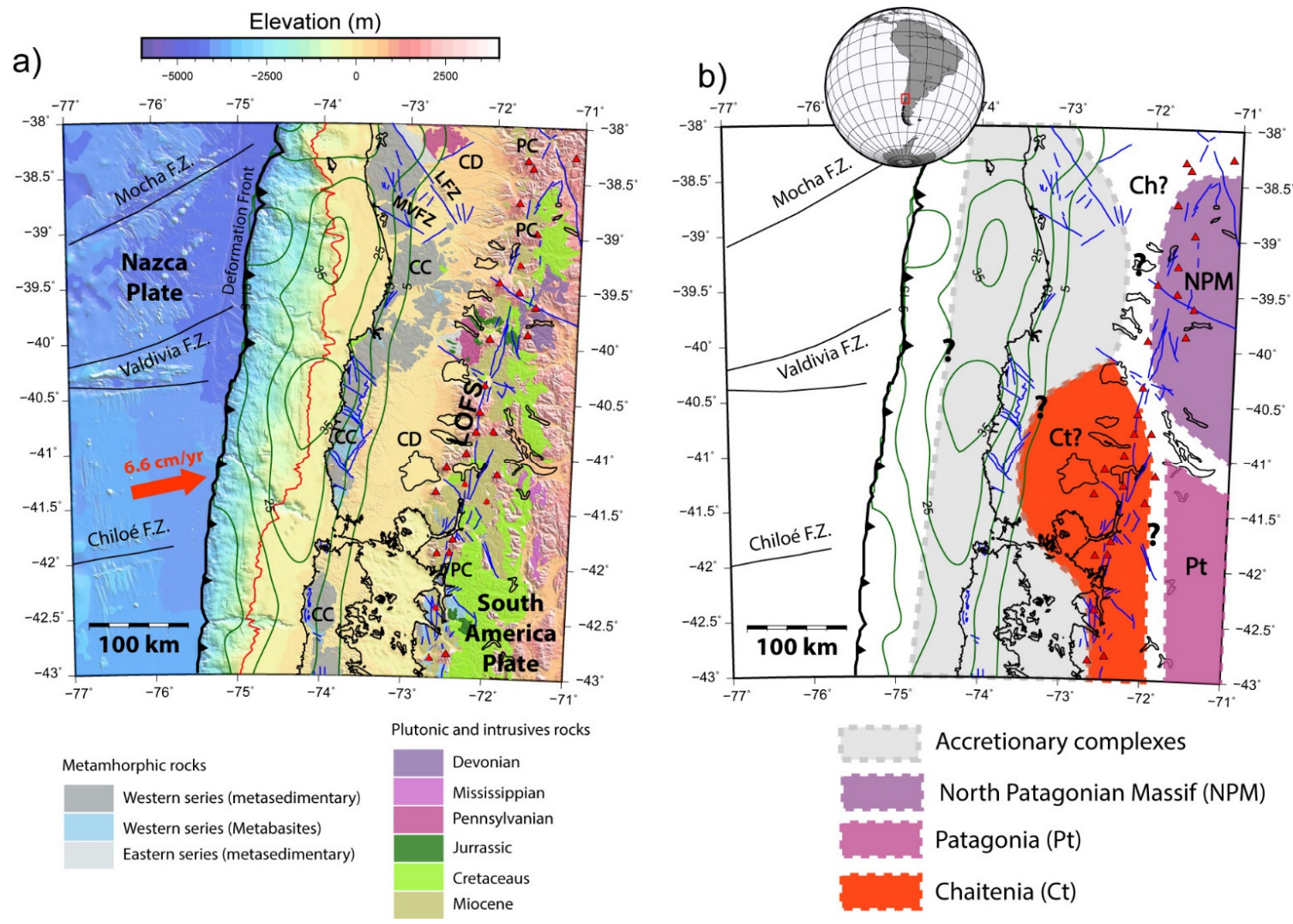
Figure 1: Geotectonic settings of the studied zone. a) Tectonic and morphostructural features above the coulored Bathymetric/topographic elevation grid. Metamorphic and Plutonic/intrusives outcrops are shown. Oceanic fracture zones (Mocha, Valdivia and Chiloé) are indicated in black. Deformation front (continental wedge toe) at the Nazca-South America trench is indicated by a bold black line. The blue lines correspond to continental structures identified at the surface (SERNAGEOMIN, 2003; Melnick and

65 Echtler, 2006), including: Liquiñe-Ofqui fault system (LOFS), Mocha-Villarrica fault zone (MVFZ) and Lanalhue fault zone (LFZ). The red triangles illustrate active volcanoes. The red arrow indicates the direction of Nazca-south America convergence and the green lines represent the iso-slip contours of Valdivia earthquake according to Moreno et al, 2009. b) Schematic map of map of basement units after Hervé et al., (2018) and other elements as in a).

\section{Geotectonic Settings}

70 The study zone, located between $38.5^{\circ} \mathrm{S}$ and $42.5^{\circ} \mathrm{S}$ (Fig. 1), is part of the South-Central Chile margin, where oceanic Nazca plate subducts beneath the continental South American plate. The current rapid convergence rate $(6.6 \mathrm{~cm}$, Angermann, 1999) determines large seismotectonic activity, including the occurrence mega-earthquakes in the zones as the giant 1960 Mw9.6 Valdivia earthquake (the largest instrumentally register worldwide). In the long-term, this subduction process has been continuously active since Jurassic times (Charrier et al. 2007), being superimposed to ancient tectonic processes of Gondwana structuration (Ramos et al, 1986), and generating the current configuration of the continental South America plate western border. Marine seismic studies, to the north and south of the researched area, indicate that the structure of the continental wedge shows a physical and tectonic segmentation from the trench to the coast, characterized by active accretionary prims along the lower slope regions, compressional geometries and the development of confined slope basins inside the middle and upper slope, while the shelf region exhibits forearc basins with a complex deformation style structured by normal and inverted faults (Bangs and Cande, 1997; Geersen et al., 2011;

80 Becerra et al. 2013; Bangs et al., 2020). Consistently, Vp models derived from wide-angle seismic refraction, at $38^{\circ} \mathrm{S}$ (ContrerasReyes et al. 2008) and south of $43^{\circ} \mathrm{S}$ (Contreras-Reyes et al., 2010), present changes in the deep structure of continental wedge that can be interpreted as transitions between accretionary prism, paleo-accretionary rocks and continental basement. Regarding to geometry of marine forearc, the continental wedge shows a narrow continental slope (defined between the deformation front and shelf break, see Fig. 1) to the south of $\sim 41^{\circ} \mathrm{S}$. This morphological change corresponds to a decrease in the slope angle at the northern region of Valdivia earthquake rupture $\left(38.5^{\circ} \mathrm{S}-41^{\circ} \mathrm{S}\right)$, which in turn, can be interpreted as a decrease in the effective fiction coefficient $\left(\mu \mathrm{b}^{*}\right)$ at the interplate boundary (Cubas et al., 2013b; Maksymowicz, 2015).

Onshore, three mayor trenches parallel morphoestructural units from west to east can be observed (Fig. 1a): (1) The Coastal Cordillera (CC) where old rocks of a paired metamorphic belt are exposed (Hervé, 1988), (2) the Central Depression (CD) characterized by the presence of unconsolidated Quaternary sediments overlay Cenozic deposits (Jordan et al., 2001), and (3) the Principal Cordillera (PC), where the active volcanic arc is currently located. In a close spatial relation with volcanic arc, the prominent Liquiñe-Ofqui Fault System (LOFS, Fig. 1) stretches along more than $1.000 \mathrm{~km}$ long between $37^{\circ} \mathrm{S}$ and $46^{\circ} \mathrm{S}(\mathrm{Cembrano}$ et al., 1996). This continental structure has been interpreted as right-lateral strike-slip system that concentrates most of the crustal seismic activity (Lange et al., 2008, Orts et al., 2012) and exhumation at these latitudes (Adriasola et al., 2005; Glodny et al., 2008). Moreover, numerous tectonic lineaments and faults zones have been described (SERNAGEOMIN, 2003; Melnick and Echtler, 2006), generally showing Northwest and Northeast orientations. According to Melnick et al. (2009), the kinematics of LOFS generates intense deformation in its northern limit, explaining the deformation associated to large north-west strike continental faults (as LFZ) and the eastward bending of the CC.

100 Accretionary metamorphic complexes, associated to late Paleozoic-early Mesozoic subduction, are exhumed along the study zone (Hervé, 1988; Duhart et al., 2001; Willner et al., 2004; Hervé et al., 2013). These units correspond to a paired metamorphic belt, which includes the Western and Eastern Series (WS/ES) formed under high P/T and low P/T conditions, respectively. WS has 

sedimentary units deformed by the basal underplating of WS units (Glodny et al., 2005, Willner et al., 2005). This paired

105 metamorphic belt is observed continuously at the CC, but the width of their outcrops varies along the margin (see Fig. 1a) presenting a landward prolongation between $\sim 38^{\circ} \mathrm{S}$ and $40^{\circ} \mathrm{S}$, and southward of $\sim 41.5^{\circ} \mathrm{S}$, outcrops of WS along the western limit of PC. Thus between $\sim 40^{\circ} \mathrm{S}$ to $\sim 41.5^{\circ} \mathrm{S}$, the onshore limit of these units is not defined due to the presence of the CD deposits, and could form most of the forearc basement or it could be confined near the coast. Westward of accretionary metamorphic complexes and north of $38^{\circ} \mathrm{S}$, the Coastal Batholith (Late Palaeozoic intrusive rocks) is observed along CC, but southward (in the study zone)

110 the outcrops of this ancient volcanic arc bends to the South East and becomes part of the PC. Younger Plutonic and intrusive rocks, related to magmatic arcs from Mesozoic to Cenozoic times (Andean tectonic Cycle), are observed along the PC near the position of active volcanic arc and LOFS, forming the North Patagonian Batholith (Charrier et al., 2007; Hervé et al., 2018; SERNAGEOMIN, 2003; SEGMAR, 1997, see Fig. 1a).

115 The continental crust of the western border of South America was configured, during Paleozoic times, by collisions of allochthonous terranes against Gondwana (Rapalini, 2005). To the north of the study zone, Chilenia terrane (Ch in Fig. 1b) collides during Devonian times (Ramos et al, 1986; Hyppolito et al., 2014, and references therein), but its southern extension is roughly defined and could be present in the northern area of the study zone. Southward, the geodynamic evolution of the margin during Devonic to Triassic times, has been explained with a double subduction system (Hervé et al., 2016). These authors proposed the development of an island arc (named as Chaitenia, Ch in Fig. 1b) parallel to the margin colliding with Gondwana during Carboniferous times (Hervé et al., 2016, 2018, Ch in Fig. 1b). If this hypothesis is correct, the continental crust of the current foreac corresponds to Chaitenia, south of $\sim 40^{\circ} \mathrm{S}$. However, it is important to point out that the limits between all these terranes are poorly constrained in the study zone owing to the scarcity of basement outcrops.

\section{Data and methods}

\section{3.1 Gravimetric database and processing}

We compile a gravimetric data base (see Fig. 2), including public databases and new measurements in the studied area. The resulting merged database include: (1) onshore gravimetric data acquired by Chilean and European institutions in the Central Andes from 1982 to 2006, originally compiled by Schmidt and Götze (2006), (2) 167 new gravimetric stations acquired by our group in 2019, (3) marine gravimetric profiles available in GEODAS database data (NOAA) and (4) satellite gravimetric grid from Sandwell

130 and Smith (Sandwell and Smith, 2009) to cover marine gaps. Bathymetric/topographic database merges onshore elevation grid (SRTM elevation grid, Jarvis et al., 2008) and swath bathymetry data of the studied zone (Flueh and Grevemeyer, 2005), complemented by Global Topography V18.1 (Smith and Sandwell, 1997).

The new gravimetric data were distributed to fill in some observed gaps in onshore studies, and to complement and validate gravity and topographic information from old stations. The gravity acquisition was made using Lacoste \& Romberg, with a digital upgrade provided by ANID-FONDECYT project $\mathrm{N}^{\circ} 11170047$. Elevation was obtained by differential GPS using Topcon HiperV instruments of the University of Chile (DGF). The data were corrected to obtain the Complete Bouguer Anomaly (CBA) using standard correction processes: tide correction, instrumental drift correction using daily repetitions at base stations, normal gravity correction (subtracting the theoretical gravity of the WGS-84 ellipsoid), Free-Air, Bouguer, and Terrain corrections. These processes were conducted considering a $2.67 \mathrm{gr} / \mathrm{cc}$ reference density. 


\subsection{Density modelling}

\subsubsection{D regional forward gravity models}

In order to study the regional structure of the continental wedge and subduction zone, we modelled five profiles (P1_Toltén, P2_Unión, P3_Osorno, P4_Llanquihue and P5_Chepu, see Fig.2), which runs perpendicular to trench at latitudes of $39.25^{\circ} \mathrm{S}$,

$14540.2^{\circ} \mathrm{S}, 40.5^{\circ} \mathrm{S}, 41^{\circ} \mathrm{S}$ and $42^{\circ} \mathrm{S}$, respectively. This profiles were extracted from the regional Complete Bouguer Anomaly grid obtained from the merged gravity database (Fig. 3). 2D forward modelling was performed by using the GravGrad modelling schema (Maksymowicz et al., 2015), allowing the calculation of the gravimetric response of a stack of layers with arbitrary shape. The densities inside each layer can be varied along the vertical and horizontal directions. As the gravity anomalies are not exclusively dependent of the density structure below each data (i.e., it should be modelling considering masses around the profile),

150 the elevation (bathymetry/topography) in 2D modelling is an averaged elevation profile which includes data inside a $\sim 40 \mathrm{~km}$ wide band around the profile (i.e., averaging the elevation to $20 \mathrm{~km}$ on each side of the gravity profile).

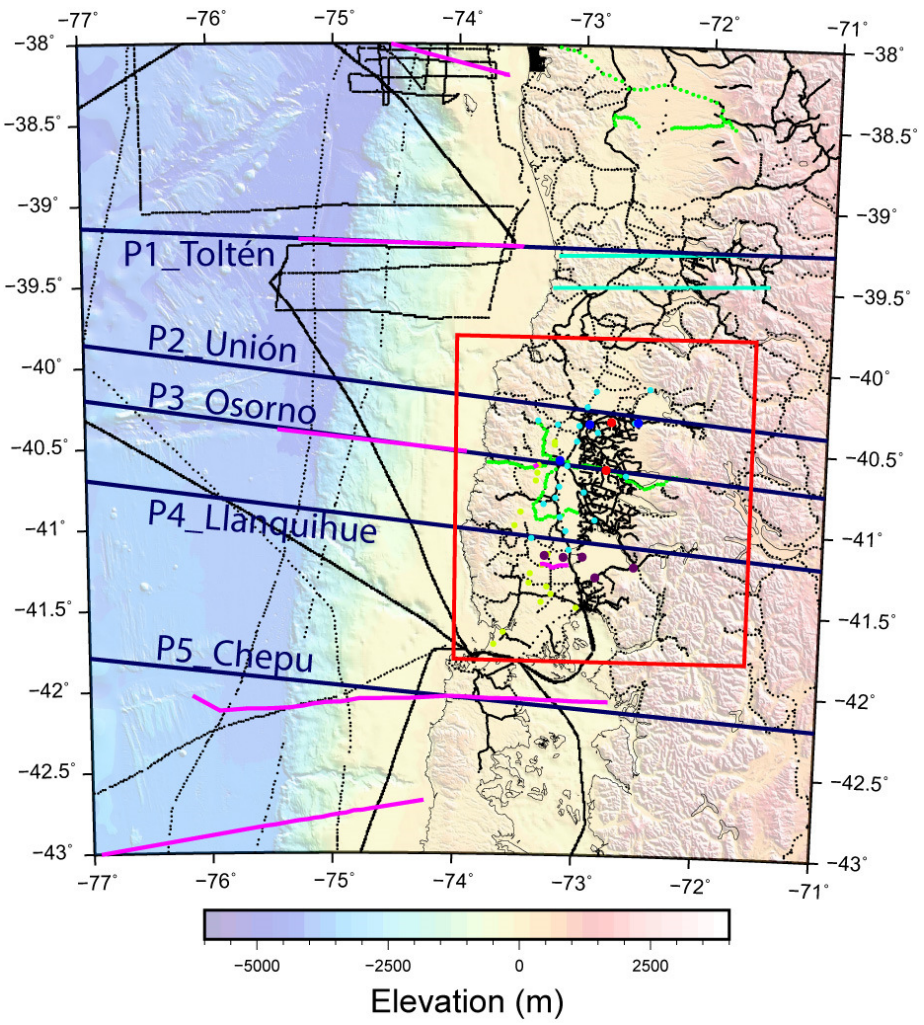

Figure 2: Geophysical database in the study zone and the location of 2D and 3D models. The blue lines indicate the location of five 2D 155 regional density model and the red rectangle is the zone in which local 3D inversion was obtained. The black dots designate gravity stations compiled by Schmidt and Götze (2006), onshore, and in GEODAS database (NOAA) offshore. The green dots illustrate the complementary gravity stations acquired by our group under the ANID-FONDECYT project $\mathbf{N}^{\circ} 11170047$. The blue and red dots correspond to TEM soundings and MT stations acquired under the aforementioned FONDECYT project. Magenta dots indicate the MT stations presented by Segovia et al. (2021) and cyan dots correspond to TEM soundings published by DGA (2012). Receiver function

160 profiles obtained by Dzierma et al., 2012a are shown with cyan lines. Location of seismic Vp-depth models (Contreras-Reyes et al., 2008; 2010; Bangs et al., 2020; Maksymowicz et al., submitted for publication) and the seismic reflection lines presented by Jordan et al. (2001) and González et al. (1989) are indicated with magenta lines. The yellow dots correspond to the location of boreholes (McDonough et al., 1997). 


\section{$165 \quad 3.2 .13 D$ gravity inversion}

Regarding a more detailed analysis of the continental density structure onshore, a 3D inversion was performed in a central patch of study zone, where a large gravity maximum is observed paralleled to the Coastal Range (red polygon in Fig. 3). This onshore 3D density model was obtained using the UBC-GIF GRAV3D v3.0 software (Li and Oldenburg 1998). The algorithm inverts Residual Bouguer Anomaly (RBA) to derive a 3D density anomaly model of the crust. The Residual Bouguer Anomaly was generated by subtracting a 1th order polynomial trend (3D plane) from Complete Bouguer Anomaly data. This linear regional gravity trend is mostly related to a deep continental root below the Andes, eastward from inverted gravity. The 3D mesh has $67 \times 80 \times 102$ blocks (in X, Y, Z direction), respectively. The horizontal grid size is $3000 \mathrm{~m}$ x $3000 \mathrm{~m}$. At depth, the cell size gradually grows from 100 to $1500 \mathrm{~m}$.

175 A total of 3514 onshore gravity data were used on the 3D inversion, generating a regular spaced grid. After numerous preliminary experiments, we selected length scale parameters of $6000 \mathrm{~m}, 6000 \mathrm{~m}$ and $3000 \mathrm{~m}$ in X, Y and Z directions, respectively. The 3D inversion was constrained by information from the geological map of 1:1.000.000 scale (SERNAGEOMIN, 2003), MT stations, TEM stations and onshore seismic lines (Fig. 2). Accordingly, we performed the inversion with the following definitions for surface sediments and basement: a minimum homogeneous thickness of $500 \mathrm{~m}$ was assigned to the entire area of the model where Quaternary sediments are exposed. These cells can take densities between $1.9 \mathrm{gr} / \mathrm{cc}$ to $2.1 \mathrm{gr} / \mathrm{cc}$. The next $500 \mathrm{~m}$ (five cells) in depth correspond to a transition zone, where the blocks could be sediments or rock and can vary between 1.9 and $2.7 \mathrm{gr} / \mathrm{cc}$. The next $300 \mathrm{~m}$ (three cells) in depth correspond to a second transitory zone, where the blocks could be fractured rock or consolidated rock, they can vary between 2.4 and $3 \mathrm{gr} / \mathrm{cc}$. Below, the blocks correspond to basement can take values between 2.5 and 3 gr/cc. Finally, we constrained the model to have greater densities than the background below $7500 \mathrm{~m}$ depth. Those deep cells can take values between 2.67 to $3 \mathrm{gr} / \mathrm{cc}$ in order to ensure more realistic vertical gradients in the lower constrained deep portion of the model.

To include the presence of main lakes in the zone, the model is forced to be water in the blocks that correspond to lake, assigning them a density of $1 \mathrm{gr} / \mathrm{cc}$. The bathymetry of the 2 first lakes was obtained from Chilean National Oceanographic Service (http://www.shoa.cl/php/inicio) and in the case of Llanqihue Lake, a mean of $200 \mathrm{~m}$ of depth was considered. Similarly, to consider the gravimetric effect of the sea, the model was forced to be water in the blocks above bathymetry.

\subsection{Geophysical constraints}

\section{3.2.1 Available geophysical information}

Independent geophysical data was used to constraint the 2D density models and onshore 3D inversion (Fig. 2). This information includes: (1) The available 2D velocity-depth models at different latitudes (Contreras-Reyes et al., 2008; 2010; Bangs et al., 2020; Maksymowicz et al., submitted for publication), used as a reference for general structure of the oceanic plate and marine continental wedge after Vp to density conversion according to the empirical Nafe-Drake transformation curve (Brocher et al. 2005). (2) Interpretation of reflection seismic profile (in depth) at $\sim 42^{\circ} \mathrm{S}$ (González et al., 1989). (3) The Quaternary sedimentary thickness and the top of the Paleozoic basement observed in the onshore ENAP seismic lines Z5B-010A and ZDO-001 (McDonough et al., 1997; Jordan et al., 2001) and ENAP boreholes (McDonough et al., 1997; Honores et al., 2015). (4) The SLAB 2.0 model (Hayes 

electrical resistivity models using magnetotelluric measurements obtained by Segovia et al. (2021), 1D electrical resistivity models from TEM measurements presented by DGA (2012), and 1D electrical resistivity models from new MT and TEM measurements were used to constraint the thickness of young sedimentary fill at CD. At the MT/TEM stations where 1D resistivity models do not reach the base of the young sedimentary fill (by cultural electromagnetic noise or limited penetration in thick sedimentary fill areas), we define values of minimum sedimentary thickness, aiming to decrease uncertainties in the density modelling.

\section{$210 \quad$ 3.2.1 Electromagnetic methods to constrain gravity measurements}

The new magnetotelluric data (red dots in Fig. 2) were collected using Metronix ADU-08 data loggers and MFS-07 induction coil magnetometers along with $\mathrm{Pb}-\mathrm{PbCl}$ electrodes. Time series data were recorded for between 12 and $24 \mathrm{~h}$. All sites were processed using the robust method based on Egbert and Booker (1986). 1D resistivity models of new and previously measured data (from

215 Segovia et al. 2021) were obtained using Occam (Constable et al. 1987) and Bostick (based on Bostick, 1977) algorithms implemented in WinGLink. See data and models in the supplementary material.

The Transient electromagnetics measurements (blue dots in Fig. 2) were carried out utilising the ABEM WalkTEM (ABEM, 2016). In general, a central loop setup was used with a transmitter loop size of $100 \times 100 \mathrm{~m} 2$ or 40 × $40 \mathrm{~m} 2$.TEM stations were modelled by using Interpex-IX1D TEM software, generating 1D resistivity depth models by Ridge Regression algorithm (see data and models in the supplementary material).

\section{Results}

\subsection{Complete Bouguer gravity Anomaly (CBA)}

225 It is necessary to describe main characteristics observed in the CBA at the study zone (Fig. 3) before analysing density models. The general aspect of the CBA is a sequence of bands with high and low gravity, roughly parallel to margin. Offshore, we observe the low CBA associated to deep trench seafloor and its sedimentary fill. It is important to notice that this low CBA extends several kilometres landward from the deformation front (toe of the continental wedge), which implies the presence of low density units at the lower slope of the continental wedge. The main feature observed in the slope and shelf area is the low CBA zone (L1 in Fig.

230 3a) extended from $\sim 38.5^{\circ} \mathrm{S}$ to $\sim 41 .^{\circ} \mathrm{S}$, correlating whit a decrease of general slope angles at same latitudes (Fig. 1). This morphologic and gravimetric anomaly is also correlated with the maximum slip patch of the giant Valdivia earthquake, as highlighted by several authors (Wells et al., 2003; Maksymowicz, 2015; Contreras-Reyes et al., 2017; see Fig. 3b).

As expected, at the onshore the regional aspect of $\mathrm{CBA}$ is an eastward trend of gravity decreases from the coast to PC, mostly 235 related to the presence of continental root below the Andes (Tassara et al., 2006; Tašárová, 2007). Therefore, high CBA anomalies are observed along the coast (Fig. 3a), but their amplitude decreases between $\sim 38.7^{\circ} \mathrm{S}$ and $\sim 40^{\circ} \mathrm{S}$, where a relative low $\mathrm{CBA}$ anomaly is observed (L2 in Fig. 3a). It is necessary to consider that L2 is spatially correlated with a zone of landward extension of the $\mathrm{CC}$ and metamorphic complex outcrops (WS/ES). 
240 To the east, a sequence of gravity lows, with sparse gravity maximums, is correlated with the eastern part of CD basin, the current volcanic arc and LOFS, suggesting a complex density structure at the PC zone. Between $\sim 40^{\circ} \mathrm{S}$ and $\sim 41.5^{\circ} \mathrm{S}$ (and probably southward) a prominent positive anomaly can be seen above the western portion of CD basin (H1 in Fig. 3a), indicating the presence of high density body elongated to the northeast and covered by sedimentary fill of CD. This interesting forearc gravity maximum was observed by Hackney et al. (2006) based on the same onshore data, and has been confirmed by our new complementary stations.

a)

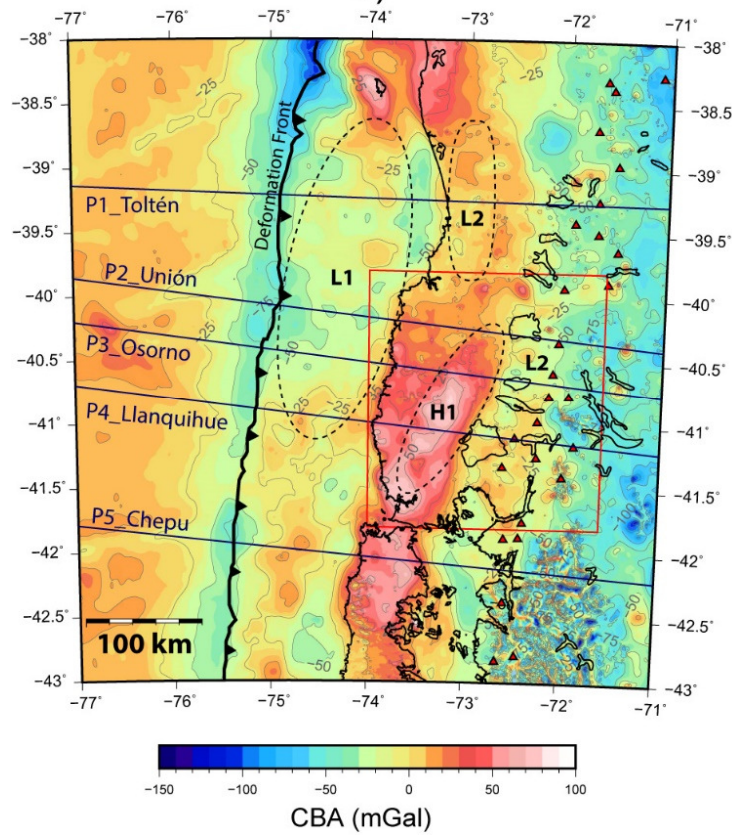

b)

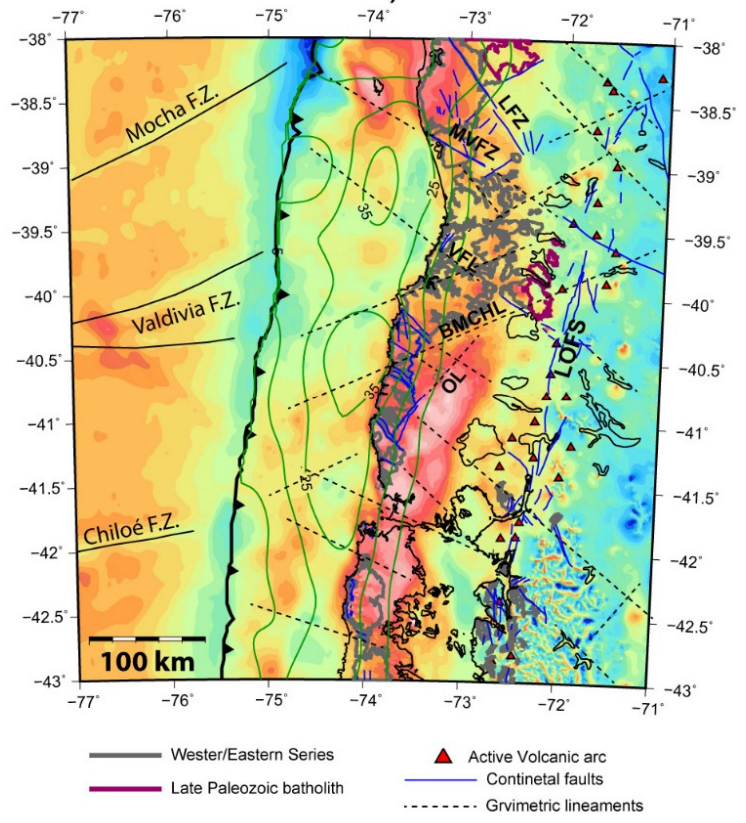

Figure 3: Complete Bouguer Anomaly (CBA) at the study zone. a) Main gravimetric forearc features observed in the area (see main text for details). The blue lines illustrate the tracks of 2D forward density models and the red rectangle indicates the zone where 3D density inversion was carried out. Dotted black ellipses shows the approximated extension of anomalies L1, L2 and $\mathrm{H1}$ along with other elements seen in Fig. 1a. b) Crustal tectonic structures and CBA. The figure includes the contours of metamorphic Western/Estern Series and Late Paleozoic batholith outcrops. Dotted black lines are interpreted gravimetric lineaments, e.g., Valdivia-Futrono lineament (VFL), Bahía Mansa-Choshuenco lineament (BMCHL) and Osorno lineament (OL). Other elements as in Fig. 1a.

255 The CBA shows a set of gravity lineaments (Fig. 3b) with north-west and north-east directions. The gravity lineaments confirm the location of fault zones previously identified at the surface (SERNAGEOMIN, 2003; Melnick and Echtler, 2006), suggesting their continuity through the forearc and, in some cases, their seaward extension (e.g., Valdivia-Futrono lineament, VFL in Fig. 3b). Additionally, new lineaments are identified in CBA, suggesting the presence of large structures affecting the basement units (e.g. Bahía Mansa-Choshuenco lineament, BMCHL in Fig. 3b). In particular, we note that H1 anomaly is limited to the north-west by the Osorno lineament (OL in Fig. 3b) which presents continuity with an identified west-dipping reverse faults in the south-west, indicating that the geometry of $\mathrm{H} 1$ has a structural/tectonic control. 


\subsection{D density profiles}

Fig. 4 shows the results of the 2D forward gravity models obtained through the five studied profiles. As observed in Fig. 4a, the modelling process allowed to attain a good fit between observed and calculated gravity data, associated to low RMS values ( $\leq 4.0$ $\mathrm{mGal}$ ) in comparison with the total amplitude of gravity anomaly. According to these results, the marine structure of the overriding plate can be described as a general landward increase of density between deformation front (DF at the trench) and the coastal area,

270 where it is possible to define at least two internal units (Fig. $4 \mathrm{~b}$ to $4 \mathrm{f}$ ): The first one corresponds to a frontal low density unit ( $\rho<$ $\sim 2.5 \mathrm{gr} / \mathrm{cc}$ ) of about $25-35 \mathrm{~km}$ wide, with a rapid landward horizontal density gradient. This frontal unit is roughly correlated with the lower slope of the continental wedge. The second unit is characterized by a lower landward horizontal density gradient and shows densities between $\sim 2.5 \mathrm{gr} / \mathrm{cc}$ to $\sim 2.8-2.9 \mathrm{gr} / \mathrm{cc}$. This middle wedge unit is extended from the lower slope to the coast by $\sim 70$ $\mathrm{km}$ at profiles P2 to P5 and is slightly wider $(\sim 90 \mathrm{~km})$ at the northernmost profile P1_Toltén. Immediately below the seafloor, all profiles present marine forearc basins with variable thicknesses $(<5 \mathrm{~km})$ and densities lower than $\sim 2.3$ gr/cc. Few kilometres before the coast, continental wedge shows a transition to higher densities landward (higher than $\sim 2.9-3.0 \mathrm{gr} / \mathrm{cc}$ in the deep portion of the crust). This transition can be described as a landward limit of the middle wedge unit and seems to have a west dipping geometry.

280 At the onshore, the upper portion of the continental forearc (the upper $\sim 10-15 \mathrm{~km}$ ) displays a sequence of low and high density zones. Below CC (and metamorphic complex outcrops), the shallow densities are generally higher than $2.5 \mathrm{gr} / \mathrm{cc}$ and increase to deep. However, this region is not particularly dense. In fact, below the sedimentary fill of CD basin we observe a high density maximum in the five 2D profiles (H1 in Fig. $4 b$ to $4 f$ ). Then, the results confirm the presence of a high density zone associated the high CBA anomaly already described (H1 in Fig. 3a), suggesting its prolongation to the north-east and south-west. Comparing the 2D profiles, we notice that $\mathrm{H} 1$ is progressively closer to the coast, southward from profile P2_Unión ( $\left.40^{\circ} \mathrm{S}\right)$, i.e., $\mathrm{H} 1$ presents a north-east trend, as suggested before in the CBA description. It is important to note that the presence of $\mathrm{H} 1$ is clear in all profiles with the exception of P2_Unión in which this density anomaly is slightly raised from a more homogenous model of the upper continental crust.

290 To the east of H1, all profiles show another high density zone (H2 in Fig. 4b to 4f), roughly located below the active volcanic arc at southern profiles P3_Osorno, P4_LLanquihe and P5_Chepu, and after the arc at the northern profiles P1_Toltén and P2_Unión. It is important toconsider that the large LOFS approximately correlates with the western limit of H2 in profiles P1_Toltén, with the eastern limit of H1 in profile P2_Unión and with the eastern border of H2 at profiles P4_LLanquihue and P5_Chepu, which suggests a structural control on the geometry of the high density anomalies and a possible relation of these anomalies with the active magmatic process in the forearc. 

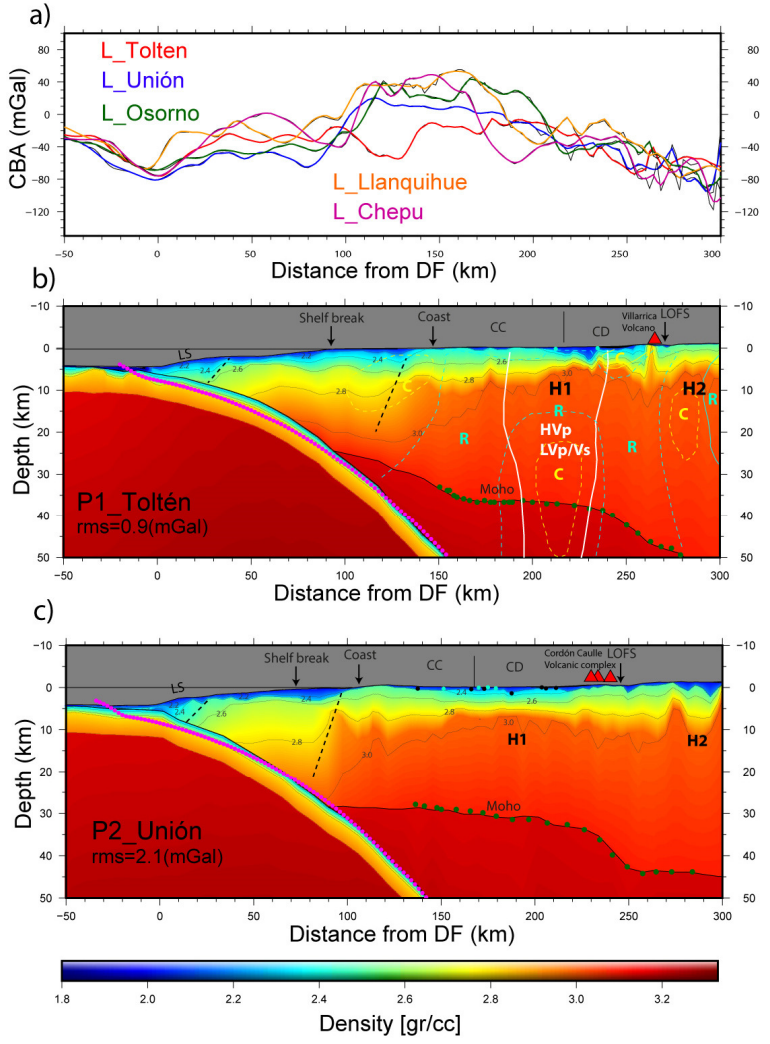

d)

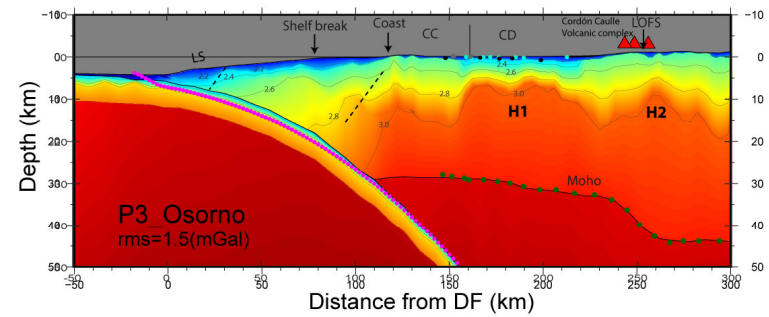

e)

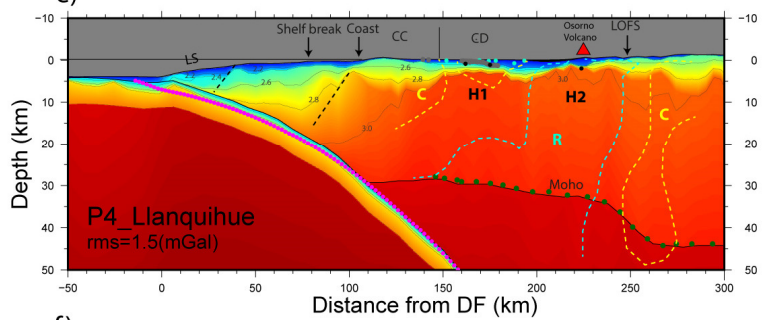

f)

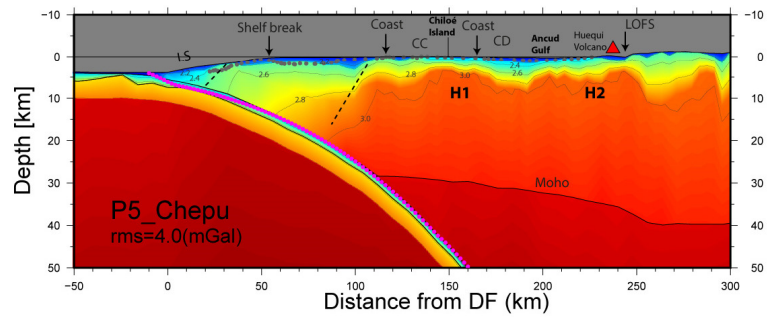

300 Figure 4: 2D regional forward models a) Complete Bouguer Anomaly (CBA) curves along five modelled profiles. Coloured curves are the modelled gravity signals and the corresponding observed data are presented in grey. b) Density depth model along the profile P1_Toltén, morphological limits of the continental wedge (as lower slope, LS) are indicated. Dotted black lines illustrate the approximate limits of frontal low density unit and the middle wedge/shelf unit of the marine continental wedge. Thin vertical line indicates the limit between $\mathrm{CC}$ and $\mathrm{CD}$. Red triangles correspond to the location of active volcanoes. Pink dots correspond to slab geometry according to

305 SLAB2.0 model (Hayes et al., 2018). Green dots depict the continental Moho depths obtained by receiver functions analysis (Dzierma et al., 2012a). Black dots indicate the base of poor compacted shallow sedimentary layer according to MT and TEM soundings and cyan dots correspond to minimum thickness of this sedimentary layer according to MT and TEM soundings. White lines limit a zone of high $\mathrm{Vp}$ and low Vp/Vs obtained by Dzierma et al. (2012b). Thin dotted yellow and cyan lines limit electrical conductive and resistive zones (C and R) according to Kapinos et al. (2016). c) Density depth model along the profile P2 Unión. d) Density depth model along the profile

310 P3_Osorno. Grey dots show the base of poor compacted shallow sedimentary layer according to ENAP boreholes (Honores et al., 2015). Other elements as in a). e) Density depth model along the profile P4 Llanquigue. Grey dots show the base of poor compacted shallow sedimentary layer according to onshore seismic profiles and ENAP boreholes (McDonough et al., 1997; Jordan et al., 2001; Honores et al., 2015). Thin dotted yellow and cyan lines limit electrical conductive and resistive zones (C and $R$ ) according to Segovia et al. (2021). Other elements as in d). f) Density depth model along the profile P5_Chepu. Grey dots represent the base of shallow sedimentary layers

315 according to seismic reflection data (González, 1989) and other elements as in a).

As is explained before, a large latitudinal change of onshore foreac continental structure is observed in the central profiles (P2_Unión, P3_Osorno and P4_Lannquihue), where H1 seems to have a north-east trend and where H2 is observed below the arc. This motivates the development of a local 3D density invasion in forearc area, to derive the detailed structure of upper continental crust with and independent model strategy. 
https://doi.org/10.5194/se-2021-53

Preprint. Discussion started: 28 May 2021

(c) Author(s) 2021. CC BY 4.0 License.

\subsection{D local density model}

The 3D inversion modelled the input Residual Bouguer Anomaly (Fig. 5a) with high precision, as is observed in Fig. 5b, where differences between modelled and observed data are, in general lower than $\pm 1 \mathrm{mGal}$. This process allows to attain density contrast anomalies to about $20 \mathrm{~km}$ depth.
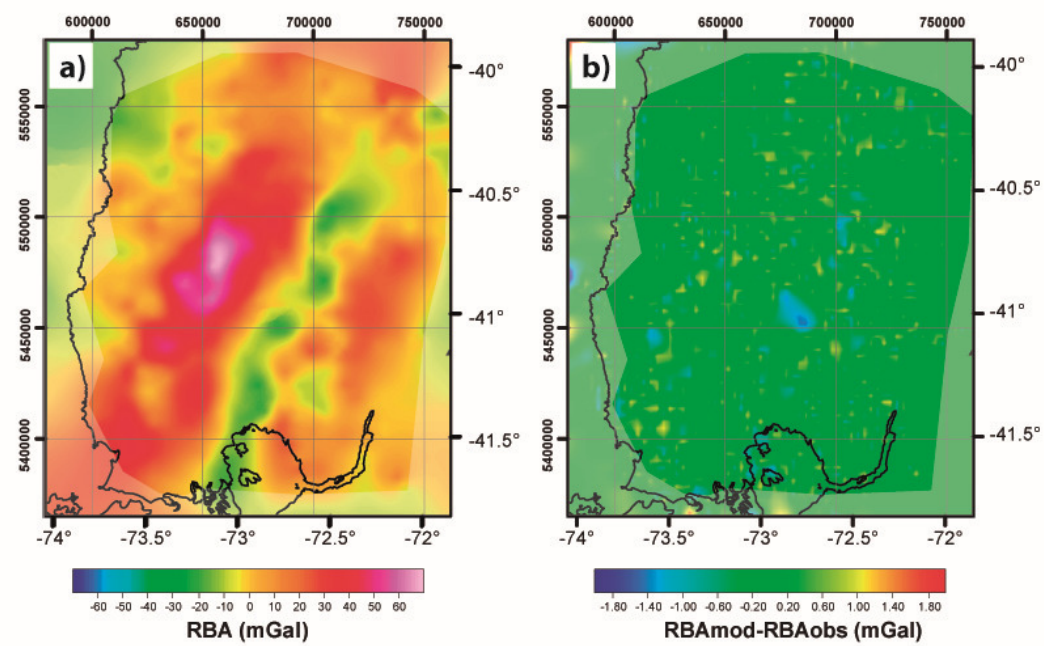

Figure 5: a) Residual Bouguer anomaly (RBA) used as input for 3D inversion b) Difference between final modelled and input RBA data.

Four constant depth slices through the final 3D model are shown in Fig. 6. In the slice at $49 \mathrm{~m}$ below sea level (Fig. 6a) it is possible to observe the geometry of the $\mathrm{CD}$ basin as yellow zones that correspond to densities contrast between $-0.77 \mathrm{gr} / \mathrm{cc}$ and $-0.57 \mathrm{gr} / \mathrm{cc}$. Also it is possible to observe the areas that correspond to seawater as blue zone with densities contrast of $-1.67 \mathrm{gr} / \mathrm{cc}$ and sedimentary areas below the lakes with densities contrast about -0.73 gr/cc. Similar density structures are observed in Fig. $6 \mathrm{~b}$ (at $1049 \mathrm{~m}$ below sea level). 

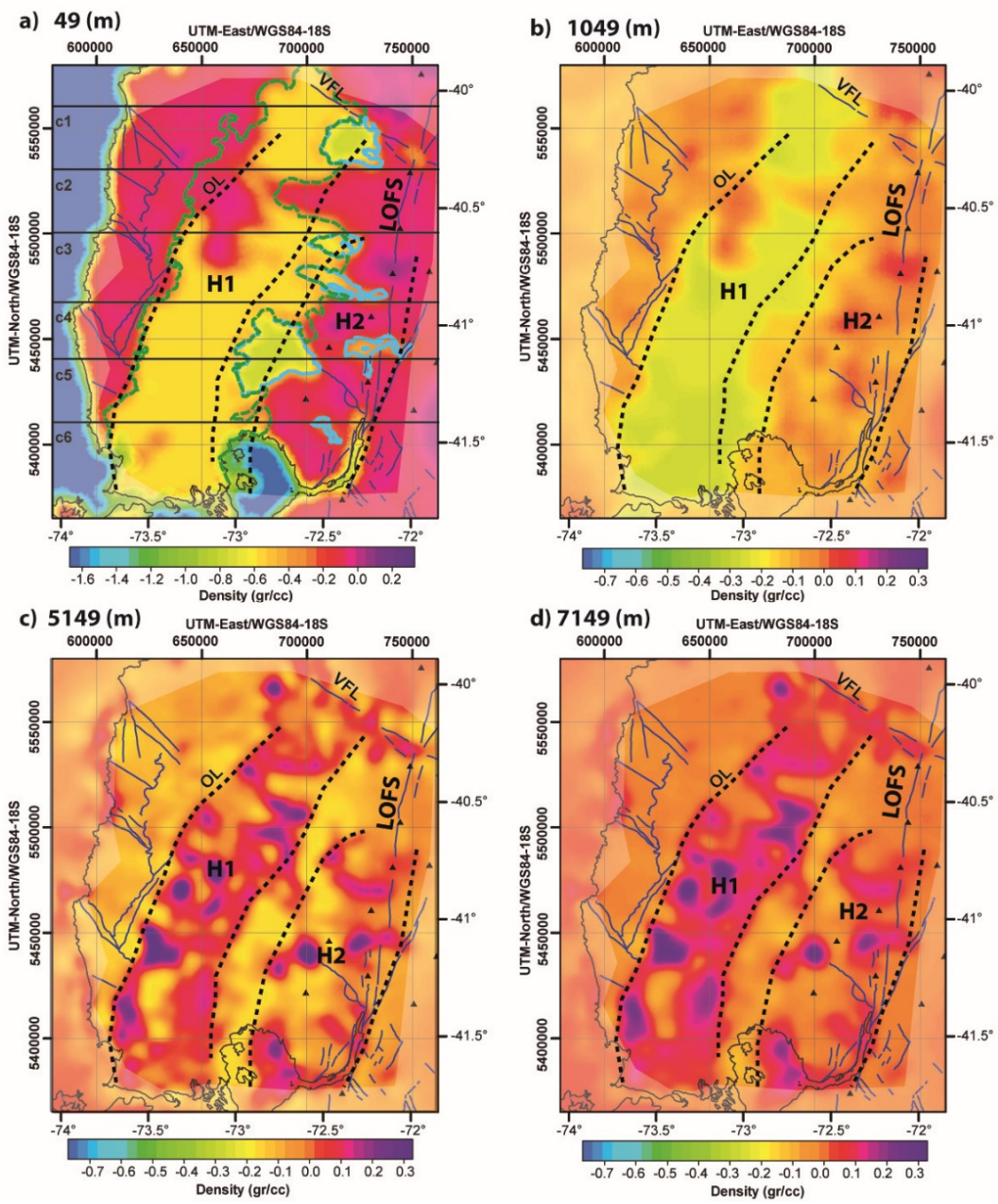

Figure 6: Density slices from the 3D density model at different depths. a) Slice at $49 \mathrm{~m}$ below the sea level. Blue lines correspond to continental structures identified at the surface (SERNAGEOMIN, 2003; Melnick and Echtler, 2006), VFL highlights the ValdiviaFutrono lineament and OL corresponds to Osorno lineament (See Fig. 3b). Segmented green line illustrates the border of CD and the external limit of the lakes are highlighted with a cyan line. Active volcanoes are marked by black triangles. Segmented black limes indicate the approximate borders of $\mathrm{H} 1$ and $\mathrm{H} 2$ density anomalies (see main text for details) defined at deeper slice showed in d). Partially hidden zones are outside of onshore data considered for 3D inversion. b) Slice at $1049 \mathrm{~m}$ below the sea level. Note the change of colour scale in relation to a). Other elements as in a). c) Slice at $5149 \mathrm{~m}$ below the sea level. Other elements as in b). d) Slice at $7149 \mathrm{~m}$ below the sea level and other elements as in b).

Fig. 6c and 6d, shows slices at $5149 \mathrm{~m}$ and $7149 \mathrm{~m}$ below sea level, respectively. At these depths it is feasible to observe the prominent high density zone H1 under the DC, being consistent with the observed one in CBA and 2D models (Fig. 3 and 4). In the 3D model, $\mathrm{H} 1$ covers $\sim 230 \mathrm{~km}$ along the strike and $\sim 80 \mathrm{~km}$ in the horizontal direction, being oriented $\sim \mathrm{N} 25^{\circ} \mathrm{E}$ to the same direction of the western border of CC. The density contrast of this structure is higher than $0 \mathrm{gr} / \mathrm{cc}$ in most of the areas, reaching 0.3 $\mathrm{gr} / \mathrm{cc}$ at denser zones. South of $\sim 40.75^{\circ} \mathrm{S}, \mathrm{H} 1$ limits with WS outcrops to the west, while to the north-west it is bordered by the OL lineament (see Fig. 3b). The northern limit of H1 correlates with the presence of VFL lineament. To the east, a low density lineament in the same $\mathrm{H} 1$ direction, with around $0 \mathrm{gr} / \mathrm{cc}$ density contrast (reaching $-0.17 \mathrm{gr} / \mathrm{cc}$ in the most pronounced areas) can be seen. This low density band is about 10 to $15 \mathrm{~km}$ wide and limits to the east with the high density zone $\mathrm{H} 2$, located below the 
active volcanic arc. The 3D density model shows variations inside $\mathrm{H} 1$ and $\mathrm{H} 2$, which are formed by high density zones (density contrast $\geq 0.3 \mathrm{gr} / \mathrm{cc}$ ) merged with lower density areas.

To analyse the density variation with depth, Fig. 7 presents six W-E vertical cross sections of the 3D model at different latitudes (c1 to c6 in Fig. 6a). All cross sections show that $\mathrm{H} 1$ is below the $\mathrm{CD}$ and correlated to the eastern limit of the CC and WS outcrops, confirming the results obtained by $2 \mathrm{D}$ regional modelling. The top of $\mathrm{H} 1$ anomaly is obtained around $5 \mathrm{~km}$ below the sea level, displaying a trend of deepening to the north (also suggested by 2D modelling). At lower scale, the geometry of H1 is characterized by two lobes and its western and eastern borders seem to be tilted to east and west, respectively (segmented black lines in Fig. 7). Eastward, $\mathrm{H} 2$ is modelled in the southern region at profiles c4, c5 and c6 (Fig. 7d to 7f) and it is also characterized by two lobes.
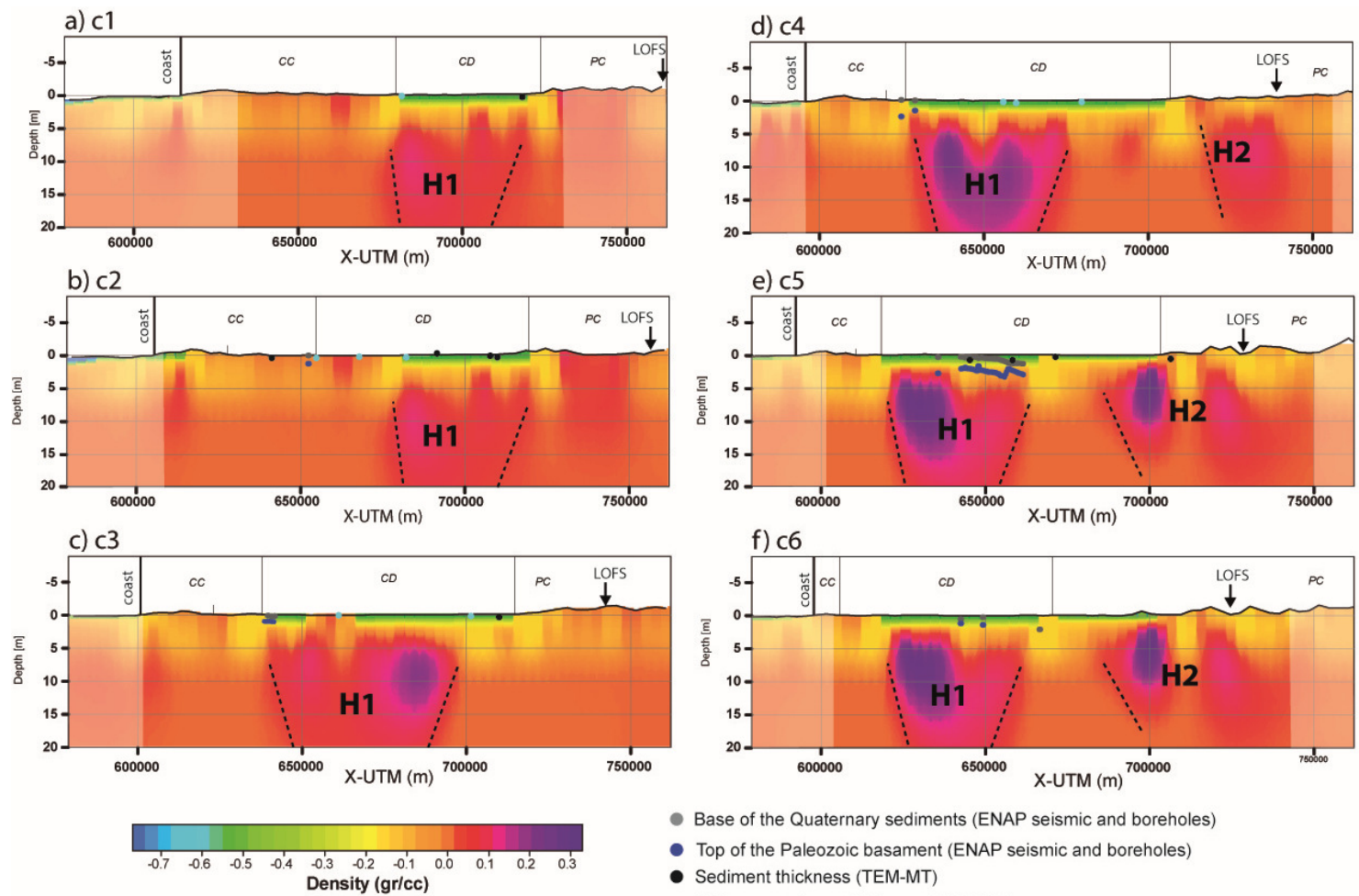

- Base of the Quaternary sediments (ENAP seismic and boreholes)

- Top of the Paleozoic basament (ENAP seismic and boreholes)

- Sediment thickness (TEM-MT)

- Minimum sediment thickness (TEM-MT)

Figure 7: Density-depth profiles extracted from 3D inversion model (see location in Fig. 6a). a) Profile c1 at UTM-North=5560500 m (WGS84-18S). Thin vertical lines indicate the limits of CC, CD. Black dots mark the base of shallow sedimentary unit, according to /MT measurements and cyan dots correspond to the minimum sedimentary fill according to the TEM/MT soundings that do not reach basement. Grey and blue dots show respectively the base of Quaternary sediment and the top of Paleozoic basement according to onshore seismic profiles and ENAP boreholes (McDonough et al., 1997; Jordan et al., 2001; Honores et al., 2015). The approximate borders of the high density anomaly $\mathrm{H1}$ are highlighted with doted black lines. The partially hidden zones are outside of onshore data considered for 3D inversion. b) Profile c2 at UTM-North=5530500 m (WGS84-18S). c) Profile c3 at UTM-North=5500500 m (WGS8418S). Grey and blue lines show the shallow sedimentary unit and the top of the metamorphic basement, according to seismic reflection profile ZDO-001 (see main text for details) and other elements as in b). d) Profile c4 at UTM-North=5467500 m (WGS84-18S). The approximate borders of the high density anomalies $\mathrm{H} 1$ and $\mathrm{H} 2$ are highlighted with doted black lines e) Profile $\mathrm{c5}$ at $\mathrm{UTM}$ T-North=5440500 $m$ (WGS84-18S). Grey and blues lines show the shallow sedimentary unit and top of the metamorphic basement, according to seismic reflection profile Z5B-010A (see main text for details) and others elements as in d). e) Profile c5 at UTM-North=5410500 m (WGS8418S). 


\section{Interpretations and discussions}

These obtained results exhibit a landward segmentation of the continental wedge density structure observed from trench to arc

385 (see and interpretative schema at Fig. 8a). Offshore, the frontal portion of continental wedge (to $\sim 25-35 \mathrm{~km}$ landward from deformation front) presents low densities with a rapid horizontal increment of densities, interpreted as compaction process in the active accretionary prism along South-Central Chilean margin (Maksymowicz et al., 2015). It is also evidenced by seismic studies in the region (Moscoso et al., 2011; Tréhu et al., 2019; Contreras-Reyes et al., 2008; 2010; Bangs and Cande, 1997; Bangs et al., 2020). To the east, below the sedimentary fill of slope and shelf basins, the continental wedge is characterized by a second unit of higher density and lower horizontal density gradient (middle wedge unit, MWU). This unit can be associated to fractured basement rocks and/or more compacted units of a paleo-accretionary prism. In this sense, Contreras-Reyes et al. (2008) at $\sim 38^{\circ} \mathrm{S}$ and Contreras-Reyes et al. (2010) at $\sim 43^{\circ} \mathrm{S}$ interpret this unit (in Vp-depth profiles) as a paleo-accretionary prims of an undetermined age between Mesozoic to Tertiary. On the other hand, at $\sim 39^{\circ} \mathrm{S}$ and $\sim 40.5^{\circ} \mathrm{S}$, bangs et al., (2020) suggest that Paleozoic-Early Mesozoic accretionary complex (WS/ES) can extend further seaward to eastern limit of active accretionary prism (seismic backstop), in accordance to the interpretation of marine seismic data (and boreholes) of González (1989) at $\sim 42^{\circ} \mathrm{S}$. However, the exploration boreholes presented by González (1989) were drilled in the shelf basin area, therefore, do not provide direct information about the age of the continental basement in the seaward portion of MWU.

Landward from MWU, the next segment correlates on the surface with the morphostructural domain of $\mathrm{CC}$ and shows a density

400 increase respecting to marine wedge, but lower densities compared to continental crust below the CD and PC. Then, this CC domain is clearly related to the Paleozoic-Early Mesozoic accretionary complexes (WS/ES) and their continuity to depth. Gravity modelling techniques does not define a downward limit of WS/ES (without independent deep constraints). Nevertheless, interpretations of seismic reflection data at $\sim 38.25^{\circ} \mathrm{S}$ (Krawczyk et al., 2006; Ramos et al, 2018) showed the downward prolongation of WS/ES reaching deep levels near continental Moho interface ( $\sim 30 \mathrm{~km}$ depth). As previously mentioned, the seaward limit of WS/ES is not defined by direct lithological observations; their presence beneath the shelf basin is confirmed by exploration boreholes (González, 1989). Thereafter, the relative rapid change in velocity associated to the transition between MWU and CC domain (dotted grey line in Fig. 8) is interpreted as a structural limit (rather than a lithological change of the basement). This structural limit is probably associated with the development of the shelf basin and a general seaward increase of fracturing within the continental wedge. This structural interpretation, seems to be confirmed by Contreras-Reyes el at. (2008) at $\sim 38.25^{\circ} \mathrm{S}$, where continental intraplate seismicity (located by Haberland et al., 2006) is aligned with this limit, and also with the intraplate seismicity located at $39.5^{\circ} \mathrm{S}$ by Dzierma et al. (2012c). 
a)

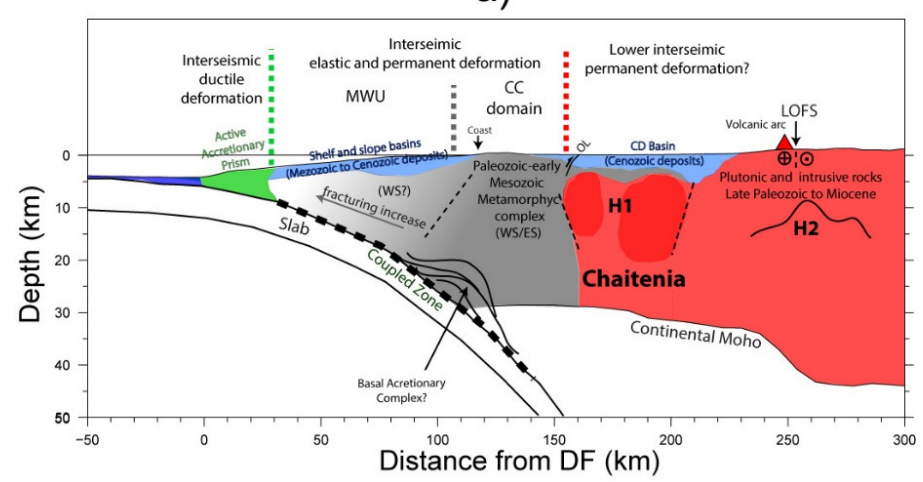

b)

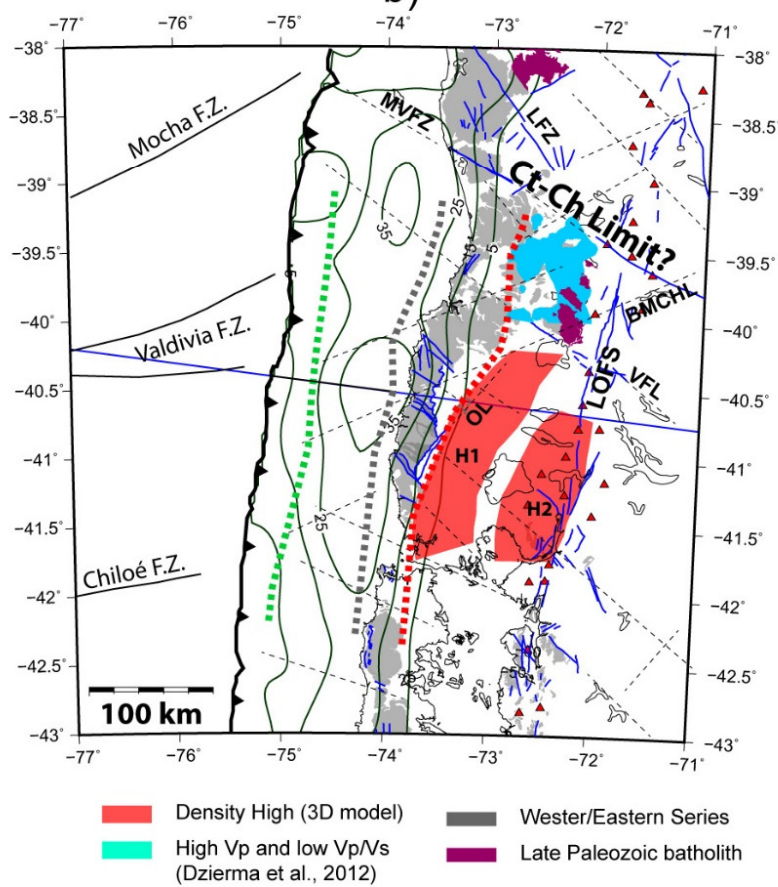

Figure 8: Schematic interpretation of continental forearc structure at regional scale. a) Interpreted profile based on 2D density model 415 along P3 Osorno line. Main geological/physical units are hatched with different colours. Light green for active accretionary prims, grey for Palaeozoic-Early Mesozoic metamorphic accretionary complex (WS/ES) and light red for high density continental crust interpreted as evidence of Chaitenia terrain in the forearc region. Dark red areas correspond to anomalies with high density contrast $(\geq 0.1 \mathrm{gr} / \mathrm{cc})$ according to 3D model along the P3_Osorno line. Light blue indicates Mesozoic to Cenozoic deposits of slope and shelf basins and Cenozoic deposits in the CD basin. Segmented green, grey and red lines indicate the landward limits of active accretionary prism, Middle wedge unit and $\mathrm{CC}$ domain (see main text for details). b) Interpretation map of continental forearc structure. Light red areas highlight the high density zones (H1 and H2) defined at $\sim 7 \mathrm{~km}$ depth in the 3D density model (Fig. 6) and cyan areas correspond to high Vp-low $\mathrm{Vp} / \mathrm{Vs}$ zone identified at $10 \mathrm{~km}$ depth by Dzierma et al. (2012b). As in a) segmented green, grey and red lines indicate the landward limits of active accretionary prism, Middle wedge unit and CC domain and other elements as in Fig. 1a and 3b)

425 The $\mathrm{CC}$ domain extends landward to the contact with the $\mathrm{H} 1$ anomaly (dotted red line in Fig. 8). The eastern border of CC range at the surface correlates almost exactly with the western border of $\mathrm{H} 1$ in the 3D model (Fig. 6 and 7), which is also observed in 2D regional profiles (Fig. 4). Accordingly, we understand that the continental crust of CC domain is deformed against a denser (and probably more rigid) block of the continental crust observed here as $\mathrm{H} 1$ anomaly. As aforementioned, the lineament OL (Fig. 1b, 
6 and 8 ) is continued to the south by a west dipping reverse fault that limits CC and CD. This is an example of the contractional

deformation styles that could be generated in the eastern border of CC by the depth contact between CC domain and $\mathrm{H} 1$ at depth. The contact between $\mathrm{CC}$ and $\mathrm{CD}$ is not always related to faults cutting the surface. Interesting is to notice that the onshore refraction seismic profile ZDO-001, located to the west of H1 (in the CC along the profile P3_Osorno, see location in Fig. 2) shows the inversion of an Oligo-Miocene normal fault, while the seismic profile Z5B-010A (located to the south of P4_Llanquihue profile) presents a minor contractional deformation in the CD sequences, above the H1 (Jordan et al., 2001).

435

In the northern profile P1_Toltén, H1 correlates with the high Vp and Low Vp/Vs anomalies obtained by Dzierma et al. (2012b). To the south, this seismic velocity anomaly shows a clear continuity with the H1 geometry noticed in the 3D density model (Fig. 8 b). This continuity indicates that $\mathrm{H} 1$ is a primary characteristic of the continental crust, southward from $\sim 39^{\circ} \mathrm{S}$, and this supports the interpretation of $\mathrm{H} 1$ as a dense-rigid zone. The latitudinal analysis of these independent geophysical models establishes that those basement units associated with $\mathrm{H} 1$ are progressively shifted to east (and taken away from the trench), northward from $41.5^{\circ} \mathrm{S}$ (Fig. 8b). In other words, the portion of the continental wedge formed by MWU and CC domain is $\sim 50 \mathrm{~km}$ wider at $39.5^{\circ} \mathrm{S}$ compared to the observed at $42^{\circ} \mathrm{S}$.

Outcrops of Late Paleozoic Batholith near $\sim 40^{\circ} \mathrm{S}$, are observed in the western border of WS/ES and H1 anomaly, possible implying that $\mathrm{H} 1$ is the southward continuation of the Late Paleozoic Batholith. However, outcrops of this Batholith are described at $\sim 40.3^{\circ} \mathrm{S}$ (Deckart et al., 2014) and $42.5^{\circ} \mathrm{S}$ (SERNAGEOMIN, 2003) near to volcanic arc, indicating a possible association of this unit with $\mathrm{H} 2$ anomaly. In this case, south of $39^{\circ} \mathrm{S}, \mathrm{H} 1$ should be a high density basement unit located westward from Late Paleozoic (Pennsylvanian) Batholith. An interesting candidate to fit this conditions is Chaitenia terrain (Ct in Fig. 1b) which is described as an island arc, accreted to the Gondwana margin (Hervé et al., 2016; 2018. The northward limit of H1 (high Vp and Low Vp/Vs anomaly, Dzierma et al., 2012b) can be roughly defined by the MVFZ. This structure could be interpreted as a limit between Chaitenia and Chilenia terrain to the north (Fig. 8b). This interpretation raises an interesting question about the role Chaitenia/Chilenia limit in the observed westward shift of the Late Paleozoic Batholith southward of $38^{\circ} \mathrm{S}$ and its relation with the continental deformation generated by the kinematics of LOFS (Cembrano et al. 1996; Melnick et al., 2009; Geersen et al., 2011).

Beyond the lithology and age of $\mathrm{H} 1$ and $\mathrm{H} 2$ anomalies it is necessary to highlight the spatial association between the active volcanism and the main lineaments of the LOFS. Most of quaternary volcanoes are located in zones with negative density contrast below $5 \mathrm{~km}$ depth (Fig. 6). The upward migration of magmas should generate a local weakening zones in the overriding plate, and consequently, the continental crust in the active volcanic zone should present pervasive fracturing, fluid migration and lower density. Hence, the basement extended to the east of $\mathrm{H} 1$ could correspond to a similar lithology, but affected by the pervasive fracturing and fluid migration processes associated to active volcanic arc and LOFS. In fact, Kapinos et al. (2016) and Segovia el al. (2021) describe electrical conductive anomalies eastward from LOFS and high resistivity values beneath the CD basin (Fig. 4b and $4 \mathrm{e}$ ). To the west of $\mathrm{H} 1$, these authors also establish conductive anomalies associated with $\mathrm{CC}$ domain, reinforcing the interpretation of a transition from highly deformed and fractured basement (related to deep units of WS/ES) to a denser/rigid basement below CD.

It is already known that the rupture propagation during large earthquakes, the intreseismic deformation (including aftershocks and foreshocks), as well as the interplate locking are complex processes that depend primary on the frictional properties at interplate boundary (subduction channel) and the stress field evolution. As aforementioned, the segment of continental wedge that includes 
MWU and CC domains, i.e. fractured and or metamorphic basement units, is progressively wider to the north of $42^{\circ} \mathrm{S}$. This structural change correlates with the patch of high coseismic slip of 1960 Mw9.6 Valdivia earthquake (Fig. 8b), which added to the correlation with gravity anomaly L1(Fig. 3a) and with changes in slope morphology, suggest a link between the megathrust seismotectonics and physical properties of the overriding plate. In this regard, we propose that the MWU and CC domains correspond to a portion of the continental plate displaying a higher elastic and permanent deformation compared to the rigid basement landward (Chaitenia/Chilenia). Consequently, the change in the horizontal extension of this unit should modified the process of stress loading during the interseismic periods.

Due to the relatively scarce seismological data in the area and the long recurrence time for large events, it is difficult to conceptualize the complete seismotectonic story of the study zone. Nevertheless, some observations seem to supports our hypothesis. Firstly, the rupture zone and aftershocks (including continental intraplate events) of the Mw 7.6 earthquake occurred in 2016 at $43.5^{\circ} \mathrm{S}$ (the largest since 1960 in the rupture area of Valdivia earthquake, Lange et al., 2018) were located at the base and within the $\mathrm{CC}$ domain, in the western border of a high Vp-low Vp/Vs anomaly (Lange, 2008). This velocity anomaly is a clear continuation of $\mathrm{H} 1$ to the south of the studied area. On the other hand, historical (not instrumentally recorded) megathrusts events activated this segment of the margin in $1737(\mathrm{Mw} \sim 7.5)$ and $1837(\mathrm{Mw} \sim 8)$. They have been associated to ruptures extended to the south of $\sim 39^{\circ} \mathrm{S}$ (Kelleher, 1974; Lomnitz 2004), indicating that the northern portion of 1960 Valdivia earthquake could have different mechanical properties.

Lithology and internal deformation style inside and at the base of MWU and CC domains can play a different but complementary physical role on the seismotectonic segmentation of the margin. The high slip patch of Valdivia earthquake also correlates with the segment where the geometry of marine continental wedge (seaward from shelf break) is consistent with a decrease in the effective friction coefficient $\left(\mu_{\mathrm{b}}^{*}\right)$ at the interplate boundary (Maksymowicz et al., 2015). This siggests oversaturate fluid conditions in the subduction channel, at least in the western portion MWU at the study zone. At the same time, according to Menant et al. (2019), the deformation style of basal accrationary complexes (typically an antiformal stack of duplexes) favoured upward fluid fluxes from the interplate boundary, generating dewatering and the increase of $\mu_{\mathrm{b}} *$ in some adjacent regions of the subduction channel (mainly downward from basal accretionary complex). Several authors have siggested the presence of this deformation style in the deep zone of WS unit (Krawczyk et al., 2006; Ramos et al, 2018, Moreno et al. 2018; Maksymowicz et al., submitted for publication). Under this interpretation, the widening of MWU and CC domains to the north of $\sim 42^{\circ} \mathrm{S}$ could favoured high friction in the deep region of interplate boundary (bellow CC domain) and a relatively low friction in the seaward portion of MWU. Therefore, the position and horizontal extension of the WS could be linked to changes in the frictional properties along the megathrust. However, more studies should be done to explore the seaward limit of WS/ES and the internal structure of MWU and

$\mathrm{CC}$ domain.

\section{Conclusions}

2D and 3D density models of the forearc show a landward and latitudinal segmentation of the continental wedge in the studied zone. Offshore, the active accretionary prism limit with a more competent basement below the middle wedge and shelf, which exhibits a landward increase of density, probably associated with a progressive decrease of fracturing. To the east, the Coastal 

anomaly below the Central Depression. Northward from $\sim 42^{\circ} \mathrm{S}$, this high density anomaly is seen progressively further from the trench, determining a northward widening of the middle wedge and Coastal Cordillera. This feature correlates with the high slip patch of the giant $1960 \mathrm{Mw} 9.6$ Valdivia earthquake

Based on geological information, we associate the middle wedge unit (at least its eastern portion) and Coastal Cordillera domain with the Late Paleozoic-Early Mesozoic accretionary complex, and the high density anomaly below the Central Depression as a geophysical evidence of Chaitenia terrain. The deformation style at the eastern border of the Costal Cordillera and seismological

515 studies support the hypothesis of a more rigid behaviour of the continental crust below the Central Depression. Accordingly, we propose that changes in the horizontal extension of the middle wedge unit and Coastal Cordillera domain should have modified the process of stress loading during the interseismic periods, and that changes in position and extension of the Late Paleozoic-Early Mesozoic accretionary complex could be linked to the frictional properties of the interplate boundary.

520 Our results highlight the role of the overriding plate structure on the seismotectonics process in subduction zones, but more studies are necessary to understand the changes in physical properties (elasticity, temperature, among others) associated with the geological story of the margin. This work motivates similar analysis of the continental basement in other subduction margins, as in the 2010 Mw8.8 Maule earthquake and Mw9.0 Tohoku-oki ruptures zones.

\section{Acknowledgments}

525 This work was funded by CONICYT/ANID under the Chilean Fondo Nacional de Desarrollo Científico y Tecnológico (FONDECYT), grant 11170047. We also thank the support of CONICYT/ANID- PIA/Anillo de Investigación en Ciencia y Tecnología ACT172002 project "The interplay between subduction processes and natural disasters in Chile".

\section{Author contribution}

AM designed the gravity experiment and DD designed MT and TEM experiments. Data acquisition was performed by AM, DMC

530 and DD. AM and DD developed the gravity data processing and 2D/3D models. MJS and DMC performed MT/TEM data processing and modelling. Interpretation and discussion was developed by AM, DMC and TR. AM prepared the manuscript with contributions from all co-authors.

\section{Competing interests}

The authors declare that they have no conflict of interest

\section{Code/Data availability}

Data, models and GravGrad routines are available at Maksymowicz, A. (2021, April 29). Forearc density structure of the overriding plate in the northern area of the giant 1960 Valdivia earthquake. Retrieved from osf.io/y9aph 
https://doi.org/10.5194/se-2021-53

Preprint. Discussion started: 28 May 2021

(c) Author(s) 2021. CC BY 4.0 License.

(c) (i)

\section{References}

Adriasola, A. C., Thomson, S. N., and Brix, M. R.: Postmagmatic cooling and late Cenozoic denudation of the North Patagonian

540 Batholith in the Los Lagos region of Chile, $41^{\circ}-42^{\circ} 15^{\prime} \mathrm{S}$, Int J. Earth. Sci. (Geol Rundsch) 95, 504-528, https://doi.org/10.1007/s00531-005-0027-9, 2005.

Angermann, D., Klotz, J., and Reigber, C.: Space-geodetic estimation of the Nazca-South America angular velocity, Earth Planet. Sci. Lett., 171, 329 - 334, 1990.

545

Bangs, N. and Cande, S.: Episodic development of a convergent margin inferred from structures and processes along the southern Chile margin, Tectonics, Vol. 16, No. 3, p. 489-503, 1997.

Bangs. N., Morgan, J. K., Tréhu, A. M., Contreras-Reyes., E., Arnul, A., Han., S., Olsen., K. M., and Zhang, E.: Basal accretion

550 along the south-central Chilean margin and its relationship to great earthquakes, J. Geophys. Res., 125, doi:10.1029/2020JB019861, 2020.

Bassett, D. and Watts, A. B.: Gravity anomalies, crustal structure, and seismicity at subduction zones: 2. Interrelationships between fore-arc structure and seismogenic behavior, Geochemistry, Geophysics, Geosystems, v. 16, p. 1541-1576, doi:10.1002/2014GC005685, 2015.

Bassett, D., Sandwell, D. T., Fialko, Y., and Watts, A. B.: Upper-plate controls on co-seismic slip in the 2011 magnitude 9.0 Tohoku-oki earthquake, Nature, 531, 92-96, 2016.

560 Becerra, J., Contreras-Reyes, E., and Arriagada, C.: Seismic structure and tectonics of the southern Arauco Basin, south-central Chile ( $\left.\sim 38^{\circ} \mathrm{S}\right)$, Tectonophysics, 592, pp. 53-66, 2013.

Bilek, S. L., Schwartz, S. Y., and DeShon, H. R.: Control of seafloor roughness on earthquake rupture behavior, Geology, 31 (5): 455-458, doi: https://doi.org/10.1130/0091-7613(2003)031<0455:COSROE>2.0.CO;2, 2003.

Bostick, F. X.: A simple almost exact method of MT analysis, Workshop on electrical methods in geothermal exploration. US Geol. Surv., 1977.

Brocher, T. M.: Empirical Relations between Elastic Wavespeeds and Density in the Earth's Crust, Bulletin of the Seismological

Society of America, 95 (6): 2081-2092, doi: https://doi.org/10.1785/0120050077, 2005.

Cembrano, J., Herve, F., and Lavenu, A.: The Liquiñe-Ofqui fault zone: a long-lived intra-arc fault system in southern Chile, Tectonophysics, 259, 55-66, 1996.

575 Charrier, R., Pinto, L., and Rodríguez, M. P.: Tectonostratigraphic evolution of the Andean Orogen in Chile, In: Moreno, T. y Gibbons, W. (eds.) The Geology of Chile, The Geological Society: 21-114, Londres, 2007. 
https://doi.org/10.5194/se-2021-53

Preprint. Discussion started: 28 May 2021

(c) Author(s) 2021. CC BY 4.0 License.

(c) (i)

Comte, D., Farías, M., Roecker, S., and Russo, R. M.: The Nature of the subduction wedge in an erosive margin: Insights from the analysis of aftershocks of the $2015 \mathrm{Mw} 8.3$ Illapel earthquake beneath the Chilean Coastal Range, Earth and Planetary Science

580 Letters, 520, 50-62, 2019.

Constable, S. C., Parker, R. L., and Constable, C. G.: Occam's inversion: A practical algorithm for generating smooth models from electromagnetic sounding data, Geophysics, 52(3), 289-300, 1987.

585 Contreras-Reyes, E., Grevemeyer, I., Flueh, E. R., and Reichert, C.: Upper lithospheric structure of the subduction zone offshore of southern Arauco peninsula, Chile at $\sim 38^{\circ}$ S, J. Geophys. Res., 113, B07303, doi:10.1029/2007JB005569, 2008.

Contreras-Reyes, E., Flueh, E., and Grevemeyer, I.: Tectonic control on sediment accretion and subduction off south central Chile: implications for co-seismic rupture processes of the 1960 and 2010 megathrust earthquakes, Tectonics, 29 (6),

$590 \quad 10.1029 / 2010$ TC002734, 2010.

Contreras-Reyes, E. and Carrizo, D.: Control of high oceanic features and subduction channel on earthquake ruptures along the Chile-Peru subduction zone, Phys. Earth Planet. Inter, 186, 49-58. http://dx.doi.org/10.1016/j.pepi.2011.03.002, 2011.

595 Contreras-Reyes, E., Maksymowicz, A., Lange, D., Grevemeyer, I., Muñoz-Linford, P., and Moscoso, E.: On the relationship between structure, morphology and large co-seismic slip: A case study of the MW 8.8 Maule, Chile 2010 earthquake, Earth and Planetary Science Letters, 478, 27-39. https://doi.org/10.1016/j.epsl.2017.08.028, 2017.

Cubas, N., Avouac, J. P., Leroy, Y. M., and Pons, A.: Low friction along the high slip patch of the 2011 Mw 9.0 Tohoku-Oki 600 earthquake required from the wedge structure and extensional splay faults, Geophys. Res. Lett., 40, 4231-4237, http://dx.doi.org/10.1002/ grl.50682, 2013a.

Cubas, N., Avouac, J. P., Souloumiac, P., and Leroy, Y. M.: Megathrust friction determined from mechanical analysis of the forearc in the Maule earthquake area, Earth Planet. Sci. Lett. (ISSN: 0012-821X) 381, 92-103, 605 http://dx.doi.org/10.1016/j.eps1.2013.07.037, 2013b.

DGA: Estudio cuencas principales Región de los Ríos / Ministerio de Obras Públicas, Dirección General de Aguas, División de Estudios y Planificación, 2012.

610 Deckart, D., Hervé, F., Fanning, C. M., Ramírez, V., Calderón, M., and Godoy, E.: U-Pb geochronology and Hf-O isotopes of zircons from the Pennsylvanian Coastal Batholith, South-Central Chile, Andean Geol., 41, pp. 49-82, 2014.

Duhart, P., McDonough, M., Muñoz, J., Martin, M., and Villeneuve, M.: El Complejo Metamórfico Bahía Mansa en la Cordillera

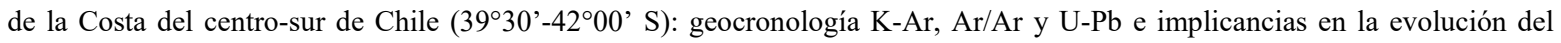
615 margen sur-occidental de Gondwana, Revista Geológica de Chile, Vol. 28, No. 2, p. 179-208, 2001. 
https://doi.org/10.5194/se-2021-53

Preprint. Discussion started: 28 May 2021

(c) Author(s) 2021. CC BY 4.0 License.

(c) (i)

Dzierma, Y., Thorwart, M., and Rabbel, W.: Moho topography and subducting oceanic slab of the Chilean continental margin in the maximum slip segment of the $1960 \mathrm{Mw} 9.5$ Valdivia (Chile) earthquake from P-receiver functions, Tectonophysics, 530-531, pp. 180-192, 2012a.

620

Dzierma, Y., Rabbel, W., Thorwart, M., Koulakov, I., Wehrmann, H., Hoernle, K., and Comte, D.: Seismic velocity structure of the slab and continental plate in the region of the 1960 Valdivia (Chile) slip maximum - Insights into fluid release and plate coupling, Earth and Planetary Science Letters, 331-332, pp. 164-176, 2012 b.

Dzierma, Y., Thorwart, M., Rabbel, W., Siegmund, C., Comte, D., Bataille, K., Iglesia, P., and Prezzi, C.: Seismicity near the slip maximum of the $1960 \mathrm{Mw} 9.5$ Valdivia earthquake (Chile): Plate interface lock and reactivation of the subducted Valdivia Fracture Zone, J. Geophys. Res., 117, B06312, doi:10.1029/2011JB008914, 2012c.

Egbert, G. and Booker, J.: Robust estimation of geomagnetic transfer functions, Geophysics, Volume 87(1), pp. 173-194, 1989. 630

Flueh, E. and Grevemeyer, I.: FS SONNE Cruise Report SO 181 Tipteq - from the incoming plate to megathrust earthquakes, Berichte aus dem Leibniz-Institut für Meereswissenschaften an der Christian-Albrechts-Universität zu Kiel 42:1-539. doi:10.3289/IFM-GEOMAR_REP_42_2011,2005.

635 Geersen, J., Behrmann, J. H., Völker, D., Krastel, S., Ranero, C.R., Diaz-Naveas, J., and Weinrebe, W.: Active tectonics of the South Chilean marine fore arc $\left(35^{\circ} \mathrm{S}-40^{\circ} \mathrm{S}\right)$, Tectonics, 30( 3), TC3006, doi:10.1029/2010TC002777, 2011.

Glodny, J., Lohrmann, J., Echtler, H., Grafe, k., Seifert, W., Collao, S., and Figueroa, O.: Internal dynamics of a paleoaccretionary wedge: Insights from combined isotope tectonochronology and sandbox modelling of the south-central Chilean forearc, Earth

640 Planet.y Sci. Lett., 231, 23- 39, 2005.

Glodny, J., Gräfe, K., Echtler, H., and Rosenau, M.: Mesozoic to Quaternary continental margin dynamics in south-central Chile $\left(36-42^{\circ} \mathrm{S}\right)$ : The apatite and zircon fission track perspective, Int. J. Earth Sci., 97, 1271- 1291, doi:10.1007/s00531-007-0203-1, 2008 .

645

González, E.: Hydrocarbon resources in the coastal zone of Chile, in Geology of the Andes and Its Relation to Hydrocarbon and Mineral Resources, edited by G. E. Ericksen et al., pp. 383-404, Cricum-Pac. Counc. for Energy and Miner. Resour., Houston, Tex., 1989.

650 Haberland, C., Rietbrock, A., Lange, D., Bataille, K., and Hofmann, S.: Interaction between forearc and oceanic plate at the southcentral Chilean margin as seen in local seismic data, Geophys. Res. Lett., 33, L23302, doi:10.1029/2006GL028189, 2006.

Hackney, R., Echtler, H., Franz, G., Götze, H. J., Lucassen, F., Marchenko, D., Melnick, D., Meyer, U., Schmidt, S., Tašárová, Z., Tassara, A., and Wienecke, S.: The Segmented Overriding Plate and Coupling at the South-Central Chilean Margin (36-42 ${ }^{\circ}$ ),

655 In:Oncken, O., et al. (Ed.), The Andes-Active Subduction Orogeny, Frontiers in Earth Sciences. Springer-Verlag, Berlin, Heidelberg, New York, pp. 355-374, 2006. 
https://doi.org/10.5194/se-2021-53

Preprint. Discussion started: 28 May 2021

(c) Author(s) 2021. CC BY 4.0 License.

(c) (i)

Hayes, G.: Slab2 - A Comprehensive Subduction Zone Geometry Model: U.S. Geological Survey data release, https://doi.org/10.5066/F7PV6JNV, 2018.

660

Hervé, F.: Late Paleozoic subduction and accretion in Southern Chile, Episodes 11: 183-188, 1988.

Hervé, F., Calderón, M., Fanning, C. M., Pankhurst, R. J., and Godoy, E.: Provenance variations in the Late Paleozoic accretionary complex of Central Chile as indicated by detrital zircons, Gondwana Research, 23, 1122-1135, 2013.

Hervé, F., Calderón, M., Fanning, C.M., Pankhurst, R.J., Fuentes, F., Rapela, C.W., Correa, J., Quezada, P., and Marambio, C.: Devonian magmatism in the accretionary complex of southern Chile, Journal of the Geological Society, 173: 587-602, doi:10.1144/jgs2015-163, London, 2016.

670

Hervé, F., Calderon, M., Fanning, C. M., Pankhurst, R. J., Rapela, C. W., and Quezada, P.: The country rocks of Devonian magmatism in the north Patagonian massif and Chaitenia, Andean Geology, 45(3), 301-317, https://doi.org/10.5027/andgeoV45n3-3117, 2018.

Hicks, S. P., Rietbrock, A., Ryder, I. M. A., Chao-Shing, L.; and Miller, M.: Anatomy of a megathrust: The 2010 M8.8 Maule, Chile earthquake rupture zone imaged using seismic tomography, Earth Planet. Sci. Lett., vol 405, 142-155, 2014.

Honores, C., Pérez, Y., Lemus, M., and Aguilera, F.: Caracterización termal de las cuencas terciarias en la Depresión Central de 680 la Región de Los Lagos mediante información geofísica, Congreso Geológico Chileno, 14, La Serena, Chile, 4 - 8 Octubre 2015 , pp.503-506 (v.2), 2015.

Hyppolito, T., Juliani, C., García-Casco, A., Meira, V. T., Bustamante, A., and Hervé, F.: The nature of the Palaeozoic oceanic basin at the southwestern margin of Gondwana and implications for the origin of the Chilenia terrane (Pichilemu region, central Chile), International Geology Review, 56:9, 1097-1121, DOI: 10.1080/00206814.2014.919612, 2014.

Jarvis, A., Reuter, H. I., Nelson, A., and Guevara, E.: Hole-filled SRTM for the globe Version 4, available from the CGIAR-CSI SRTM 90 m Database. http://srtm.csi.cgiar.org, 2008.

690 Jordan, T. E., Burns, W. M., Veiga, R., Pángaro, F., Copeland, P., Kelley, S., and Mpodozis, C.: Extension and basin formation in the southern Andes caused by increased convergence rate: A mid-Cenozoic trigger for the Andes, Tectonics, 20, 308-324, 2001.

Kapinos, G., Montahaei, M., Meqbel, N., and Brasse H.: Three-dimensional electrical resistivity image of the South-Central Chilean subduction zone, Tectonophysics, 666, 76-89, 2016. 
https://doi.org/10.5194/se-2021-53

Preprint. Discussion started: 28 May 2021

(c) Author(s) 2021. CC BY 4.0 License.

(c) (i)

Kelleher, J. A.: Rupture zones of large South American earthquakes and some predictions, J. Geophys. Res., 77( 11), 2087-2103, doi:10.1029/JB077i011p02087, 1972.

Kodaira, S., No, T., Nakamura, Y., Fujiwara, T., Kaiho, Y., Miura, S., Takahashi, N., Kaneda, Y., and Taira, A.: Coseismic fault rupture at the trench axis during the 2011 Tohoku-oki earthquake, Nat. Geosci., 5, 646-650, doi:10.1038/ngeo1547, 2012.

Krawczyk, C. M., Mechie, J., Lüth, S., Tašárová, Z., Wigger, P., Stiller, M., Brasse, H., Echtler, H. P., Araneda, M., and Bataille. K.: Geophysical signatures and active tectonics at the south-central Chilean margin, In:Oncken, O., et al. (Ed.), The Andes-Active Subduction Orogeny. Frontiers in Earth Sciences. Springer-Verlag, Berlin, Heidelberg, New York, pp 171-192, 2006.

Lange, D., Cembrano, J., Rietbrock, A., Haberland, C., Dahm, T., and Bataille, K.: First seismic record for intra-arc strike-slip tectonics along the Liquiñe-Ofqui fault zone at the obliquely convergent plate margin of the southern Andes, Tectonophysics, 455(1-4), 14-24, 2008.

710 Lange, D.: The South Chilean subduction zone between $41{ }^{\circ} \mathrm{S}$ and $43.5 \circ \mathrm{S}$ : seismicity, structure and state of stress, $\mathrm{PhD}$ thesis, University of Potsdam, https://publishup.uni-potsdam.de/opus4-ubp/frontdoor/index/index/docId/1738, 2008.

Lange, D., Ruiz, J., Carrasco, S., and Manríquez, M.: The Chiloé Mw 7.6 earthquake of 2016 December 25 in Southern Chile and its relation to the Mw 9.5 1960 Valdivia earthquake, Geophysical Journal International, Volume 213, Issue 1, Pages 210-221, https://doi.org/10.1093/gji/ggx514, 2018.

León-Ríos, S., Ruiz, S., Maksymowicz, A., Leyton, F., Fuenzalizada, A., and Madariaga, R.: Diversity of the Iquique's foreshocks and aftershocks: a clue about complex rupture process of a Mw 8.1 earthquake, J. Seismol, 10.1007/s10950-016-9568-6, 2016.

Li, D. and Liu, Y.: Modeling slow-slip segmentation in cascadia subduction zone constrained by tremor locations and gravity anomalies, J. Geophys. Res., 122 (4), pp. 3138-3157, 2017.

Li, Y. and Oldenburg, D.W.: 3-D inversion of gravity data, Geophysics, 63(1), 109-119, 1998.

Lomnitz, C.: Major Earthquakes of Chile: A Historical Survey, 1535-1960, Seismological Research Letters, 75 (3): 368-378. doi: https://doi.org/10.1785/gssrl.75.3.368, 2004.

Maksymowicz, A.: The geometry of the Chilean continental wedge: tectonic segmentation of subduction processes off Chile,

Tectonophysics, 659, pp. 183-196, 2015.

Maksymowicz, A., Tréhu, A. M., Contreras-Reyes, and E., Ruiz, S.: Density-depth model of the continental wedge at the maximum slip segment of the Maule Mw8. 8 megathrust earthquake, Earth Planet. Sci. Lett., 409, pp. 265-277, 2015. 
https://doi.org/10.5194/se-2021-53

Preprint. Discussion started: 28 May 2021

(c) Author(s) 2021. CC BY 4.0 License.

(c) (i)

735 Maksymowicz, A., Chadwell, C. D., Ruiz, J., Tréhu, A. M., Contreras-Reyes, E., Weinrebe, W., Díaz-Naveas, J., Gibson, J. C., Lonsdale, P., and Tryon, M. D.: Coseismic seafloor deformation in the trench region during the Mw8.8 Maule megathrust earthquake, Scientific Reports, v. 7, 45918, https:// doi .org /10 .1038/srep45918, 2017.

Maksymowicz, A., Ruiz, J., Vera, E., Contreras-Reyes, E., Ruiz, S., Arriagada, C., Bonvalot, S., and Bascuñan, S.: Heterogeneous

740 structure of the Northern Chile marine forearc and its implications for megathrust earthquakes, Geophys. J. Int., 215 (2), pp. 10801097, 10.1093/gji/ggy325, 2018.

Maksymowicz, A., Contreras-Reyes, E., Diaz., D., Comte, D., Bangs, N., Tréhu, A. M., Vera, E., Hervé, F., and Rietbrock, A.: Deep structure of the continental plate in South-Central Chile margin: metamorphic wedge and implications for large megaearthquake rupture processes, Journal of Geophysical Research, Submitted for publication.

Martínez-Loriente, S., Sallarès, V., R. Ranero, C., B. Ruh, J., Barckhausen, U., Grevemeyer, I., and Bangs, N.: Influence of incoming plate relief on overriding plate deformation and earthquake nucleation: Cocos Ridge subduction (Costa Rica), Tectonics, 38, 4360-4377, https://doi.org/10.1029/2019TC005586, 2019.

750

McDonough, M., Duhart, P., and Crignola, P.: Naturaleza del alzamiento del basamento costero y la apertura de la cuenca OsornoLlanquihue, Xa Región: nuevos antecedentes sísmicos y observaciones de terreno, In Congreso Geológico Chileno, No. 8, Actas, Vol. 1, p. 164-168. Antofagasta, 1997.

Melnick, D. and Echtler, H. P.: Morphotectonic and geologic digital map compilations of the south-central Andes (36-42 $\mathrm{S})$, In: Oncken, O., Chong, G., Franz, G., Giese, P.,Götze, H.-J., Ramos, V.A., Strecker, M., Wigger, P. (Eds.), The Andes - Active Subduction Orogeny. Frontiers in Earth Science Series, Vol. 1. Springer-Verlag, Berlin, Heidelberg, New York, pp. 565-568, 7602006

Melnick, D., Bookhagen, B., Strecker, M.R., and Echtler, H. P.: Segmentation of megathrust rupture zones from fore-arc deformation patterns over hundreds to millions of years, Arauco peninsula, Chile., J. Geophys. Res., 114, B01407, doi:10.1029/2008JB005788, 2009.

Menant, A., Angiboust, S., and Gerya, T.: Stress-driven fluid flow controls long-term megathrust strength and deep accretionary dynamics, Sci. Rep., 9:9714. doi: 10.1038/s41598-019-46191-y, 2019.

Moreno, M. S., Bolte, J., Klotz, J. and Melnick, D.: Impact of megathrust geometry on inversion of coseismic slip from geodetic

data: Application to the 1960 Chile earthquake, Geophys. Res. Lett. 36, L16310, 2009.

Moreno, M., Li, S., Melnick, D., Bedford, J. R., Baez, J. C., Motagh, M., Metzger, S., Vajedian, S., Sippl, C., Gutknecht, B. D., Contreras-Reyes, E., Deng, Z., Tassara, A., and Oncken, O.: Chilean megathrust earthquake recurrence linked to frictional contrast at depth, Nature Geoscience, 11(4), 285. https://doi.org/10.1038/s41561-018-0089-5, 2018. 
https://doi.org/10.5194/se-2021-53

Preprint. Discussion started: 28 May 2021

(c) Author(s) 2021. CC BY 4.0 License.

(c) (i)

Moscoso, E., Grevemeyer, I., Contreras-Reyes, E., Flueh, E.R., Dzierma, Y., Rabbel, W., and Thorwart, M.: Revealing the deep structure and rupture plane of the 2010 Maule, Chile earthquake $(\mathrm{Mw}=8.8)$ using wide angle seismic data, Earth Planet. Sci. Lett., 307, 147- 155, doi:10.1016/j.eps1.2011.04.025, 2011.

780 Orts, D. L., Folguera, A., Encinas, A., Ramos, M., Tobal, J., and Ramos, V. A.: Tectonic development of the North Patagonian Andes and their related Miocene foreland basin $\left(41^{\circ} 30^{\prime}-43^{\circ} \mathrm{S}\right)$, Tectonics, 31(3), 2012.

Peacock, S. M. and R. D.: Hyndman, Hydrous minerals in the mantle wedge and the maximum depth of subduction thrust earthquakes, Geophys. Res. Lett., 26, 2517-2520, 1999.

Poli, P., Maksymowicz, A., and Ruiz, S.: The Mw 8.3 Illapel earthquake (Chile): Preseismic and postseismic activity associated with hydrated slab structures, Geology; 45 (3): 247-250, doi: https://doi.org/10.1130/G38522.1, 2017.

790 Ramos, V. A., Jordan, T. E., Allmendinger, R. W., Mpodozis, C., Kay, S. M., Cortés, J. M., and Palma, M.: Paleozoic terranes of the central Argentine-Chilean Andes, Tectonics, 5(6), 855-880, doi:10.1029/TC005i006p00855, 1986.

Ramos, C., Mechie, J., and Stiller, M.: Reflection seismic images and amplitude ratio modelling of the Chilean subduction zone at $38.25^{\circ} \mathrm{S}$, Tectonophysics. 747-748, 115-127, 2018.

795

Rapalini, A. E.: The accretionary history of southern South America from the latest Proterozoic to the Late Paleozoic: some paleomagnetic constraints, A.P.M. Vaughan, P.T. Leat, R.J. Pankhurst (Eds.), Terrane Processes at the Margins of Gondwana, Special Publication, vol. 243, Geological Society of London, pp. 305-328, 2005.

800 Sandwell, D. T. and Smith, W. H. F.: Global marine gravity from retracked Geosat and ERS-1 altimetry: ridge segmentation versus spreading rate, J. Geophys. Res., 114, B01411, http://dx.doi.org/10.1029/2008JB006008, 2009.

Scholz, C. H.: Earthquakes and friction laws, Nature, 391, 37-42, 1998.

805 Schurr, B., Moreno, M., Tréhu, A. M., Bedford, J., Kummerow, J., Li, S., and Oncken, O.: Forming a Mogi doughnut in the years prior to and immediately before the 2014 M8.1 Iquique, northern Chile earthquake, Geophysical Research Letters, 47, e2020GL088351, https://doi.org/10.1029/2020GL088351, 2020.

SEGMAR.: Mapa Geologico de la Republica Argentina, Escala 1:2.500.000, Servicio Geologico y Minero, Buenos Aires, 810 Argentina, 1997.

Segovia, M. J., Diaz, D., Slezak, K., and Zuñiga, F.: Magnetotelluric study in the Los Lagos Region (Chile) to investigate volcanotectonic processes in the Southern Andes, Earth Planets Space, 73, 5, https://doi.org/10.1186/s40623-020-01332-w, 2021. 
https://doi.org/10.5194/se-2021-53

Preprint. Discussion started: 28 May 2021

(c) Author(s) 2021. CC BY 4.0 License.

(c) (i)

815 Seno, T.: Variation of downdip limit of the seismogenic zone near the Japanese islands: Implications for the serpentinization mechanism of the forearc mantle wedge, Earth Planet. Sci. Lett., 231, 249-262, doi:10.1016/j.epsl.2004.12.027, 2005.

SERNAGEOMIN: Geologic map of Chile, digital version, scale 1:1000000, 2003.

820 Schmidt, S. and Götze, H. -J.: Bouger and isostatic maps of the Central Andes, In The Andes-active subduction orogeny, Frontiers in Earth Sciences, 1, 559-563. Eds. Oncken, O., Chong, G., Franz, G., Giese, P., Götze, H. -J., Ramos, V. A., Strecker, M., and Wigger, P. Springer-Verlag, Heidelberg, 2006.

Smith, W. H. F. and Sandwell, D. T.: Global seafloor topography from satellite altimetry and ship depth soundings, Science, 277 , 1957-1962, 1997.

Song, T. A. and Simons, M.: Large trench-parallel gravity variations predict seismogenic behavior in subduction zones, Science. 301, 630-633, 2003.

830 Tašárová, Z. A.: Towards understanding the lithospheric structure of the southern Chilean subduction zone $\left(36^{\circ} \mathrm{S}-42^{\circ} \mathrm{S}\right)$ and its role in the gravity field, Geophysical Journal International, Volume 170, Issue 3, Pages 995-1014, https://doi.org/10.1111/j.1365246X.2007.03466.x, 2007.

Tassara, A., Götze, H. -J., Schmidt, S., and Hackney, R.: Three-dimensional density model of the Nazca plate and the Andean 835 continental margin, J. Geophys. Res., 111, B09404, doi:10.1029/2005JB003976, 2006.

Tassara, A.: Control of forearc density structure on megathrust shear strength along the Chilean subduction zone, Tectonophysics, 495, 34-47, 2010.

840 Tréhu, A.M., Hass, B., de Moor, A., Maksymowicz, A., Contreras-Reyes, E., Vera, E., and Tryon, M.D.: Geologic controls on up-dip and along-strike propagation of slip during subduction zone earthquakes from a high-resolution seismic reflection survey across the northern limit of slip during the 2010 Mw8.8 Maule earthquake, offshore Chile, Geosphere, v. 15, no. 6, p. 1751-1773, https://doi.org /10.1130/GES02099.1, 2019.

845 Tsuji, T., Minato, S., Kamei, R., Tsuru, T., and Kimura, G.: 3D geometry of a plate boundary fault related to the 2016 Off-Mie earthquake in the Nankai subduction zone, Japan, Earth. Planet. Sci. Lett., 478:234-244. https://doi.org/10.1016/j.epsl.2017.08.041, 2017.

van Dinther, Y., Morra, G., Funiciello, F., Rossetti, F., and Faccenna, C: Exhumation and subduction erosion in orogenic wedges: 850 insights from numerical models, Geochem. Geophys. Geosyst., 13, Article Q06003, 10.1029/2011GC004011, 2012. 
https://doi.org/10.5194/se-2021-53

Preprint. Discussion started: 28 May 2021

(c) Author(s) 2021. CC BY 4.0 License.

Wang, K., Huang, T., Tilmann, F., Peacock, S. M., and Lange, D.: Role of Serpentinized mantle wedge in affecting Megathrust Seismogenic behavior in the area of the $2010 \mathrm{M}=8.8$ Maule earthquake, Geophysical Research Letters, 47, e2020GL090482.

855 https://doi.org/10.1029/2020GL090482, 2020.

Wells, R. E., Blakely, R. J., Sugiyama, Y., Scholl, D. W., and Dinterman, P. A.: Basin-centred asperities in great subduction zone earthquakes: A link between slip, subsidence, and subduction erosion, Journal of Geophysical Research, 108 (B10), 2507-2537, 2003.

860

Willner, A. P., Glodny, J., Gerya, T. V., Godoy, E. and Massonne, A.: A counterclockwise PTt-path of high pressure-low temperature rocks from the coastal Cordillera accretionary complex of South Central Chile: constraints for the earliest stage of subduction mass flow, Lithos, 75: 283-310, 2004.

865 Willner, A. P.: Pressure-Temperature Evolution of a Late Palaeozoic Paired Metamorphic Belt in North-Central Chile (3435³0'S), Journal of Petrology, Volume 46, Issue 9, Pages 1805-1833, https://doi.org/10.1093/petrology/egi035, 2005. 